\title{
Efficiency Convergence in Islamic and Conventional Banks
}

\author{
Jill Johnes • Steven Ongena* • Vasileios Pappas • Mike Tsionas • Marwan Izzeldin
}

September 2018

\begin{abstract}
This paper examines how efficiency dynamics of Islamic and conventional banks compare and how they are converging across different countries. We employ both parametric and nonparametric methods to analyse a panel of Islamic and conventional banks from 23 countries during the period 1999 to 2014. Parametric methods (stochastic frontiers methods) shows that both steady state efficiency and the speed of convergence of Islamic and conventional banks are similar. A non-parametric framework (classification trees) identifies a varying degree of alignment between the Islamic and conventional banking model across countries, which could explain the plurality in conclusions in the Islamic/conventional bank efficiency debate. We find that the alignment between the two bank types is positively related to the country's financial depth, transparency, economic stability and banking concentration. At the bank level, the alignment in the two banking systems is associated with higher income diversification, liquidity, profitability and financial stability.
\end{abstract}

Keywords: Efficiency convergence $\bullet$ Random parameter estimation $\bullet$ Conditional $\beta$ convergence $\bullet$ Islamic banks $\bullet$ Classification trees

JEL classification: $\mathrm{G} 21 \cdot \mathrm{F} 36 \cdot \mathrm{D} 24$

\footnotetext{
* Corresponding author (steven.ongena@bf.uzh.ch). The authors are affiliated with: The Business School, University of Huddersfield, Queensgate, Huddersfield HD1 3DH, UK (Johnes), the University of Zurich, IBF, Plattenstrasse 32, Zürich 8032, Switzerland (Ongena), the University of Kent, Sail and Colour Loft, Chatham, Kent ME4 4TE (Pappas) and the Lancaster University Management School, Lancaster University, Bailrigg, Lancaster LA1 4YX, UK (Tsionas, Izzeldin). The authors are grateful to participants in the 4th Islamic Banking and Finance Conference (Lancaster), the 5th International Conference of the Financial Engineering and Banking Society (Nantes), and the INFINITI Conference (Dublin) for valuable suggestions. The authors also want to thank Konstantinos Baltas, Iftekhar Hassan and Gerry Steele for their many helpful comments. The authors acknowledge academic support from the GulfOne Lab for Computational and Economic Research (GOLCER).
} 


\section{Introduction}

Banking efficiency studies have long been of interest to a variety of stakeholders. ${ }^{1}$ At a macro level, there is some evidence that economic growth (as measured by growth in GDP) is significantly and positively related to banking sector efficiency (Abedifar et al., 2016; Berger et al., 2004; Hasan et al., 2009). At a micro level, efficiency studies can provide benchmarking information that will be of interest to bank managers and policy makers in order to improve banks' performance.

Banking efficiency has also been widely studied in comparative banking analyses, notably when comparing Islamic and conventional banks; see Johnes et al., (2014) for a comprehensive review of empirical studies on efficiency of these two bank types. Measuring efficiency in Islamic banking is particularly important in countries where this type of banking accounts for a substantial part of the financial sector. The cases of Saudi Arabia and Malaysia, where the share of Islamic banking assets are $51.2 \%$ and $21.3 \%$, respectively, are important examples (Ernst \& Young, 2016). In addition, the efficiency of operations of Islamic banks that co-exist with their conventional counterparts has a significant positive effect on the development of a country's entire banking sector (Gheeraert, 2014).

A number of studies comparing the efficiency of the Islamic and conventional banking sectors have identified a significant efficiency gap between the two bank types at given points in time and for a variety of countries (Abdul-Majid et al., 2010; Al-Muharrami, 2008; Johnes et al., 2014; Kamarudin et al., 2014; Srairi, 2010). Given the observed differences between the Islamic and conventional banking business models, the variations in efficiency dynamics are perhaps to be expected. However, the underlying dynamics of this efficiency have barely been examined. Examining banking efficiency and related dynamics warrants an investigation as it is closely related to bank risk-taking and capitalisation (Kwan and Eisenbies, 1997; Altunbas et al., 2007). Furthermore, the ever-increasing competition in the financial services industry (Fiordelisi et al., 2011) places efficiency at the forefront of bank managers, regulators and policy makers' agendas. In light of the importance of efficiency measurement and related dynamics, this paper addresses three questions regarding the Islamic and conventional banking business models. First, do Islamic and conventional banks have different steady state efficiency levels? Second, do Islamic and conventional banks have different rates / dynamics of efficiency convergence? Third, are Islamic and conventional banks more aligned in certain countries with respect to efficiency dynamics, and if so what are the drivers of this behaviour?

We address the above questions using various approaches and techniques. First, we use a stochastic frontier output distance function (ODF) to provide estimates of efficiency. Second, a conditional $\beta$-convergence model with Islamic bank shift and slope dummies is estimated using pooled OLS, random effects (RE) and system-GMM. A random parameter model

\footnotetext{
${ }^{1}$ The number of citations to the seminal papers by Aigner et al., (1977) and Charnes et al., (1978) on stochastic frontier analysis (SFA) and data envelopment analysis (DEA) jointly equal around 40,000, while the number of citations to Berger and Humphrey, (1997) and Berger and Mester (1997), the two seminal reviews on banking efficiency, are around to 4,200 and 2,600 respectively.
} 
(RPM) that allows for both the steady state efficiency and the $\beta$-coefficient to vary by bank is also used. These estimation techniques allow for an increasing degree of heterogeneity in the convergence process across years, countries and bank types, while mitigating potential endogeneity concerns.

Third, we utilise a classification trees approach that offers a way to identify whether there are groups of banking systems which are similar in terms of steady state efficiency and efficiency convergence rate. This approach, novel in this context, is necessary for the following reasons. The fact that the substantial literature on the comparative efficiency of Islamic and conventional banks has reached no consensus on which of the two banking systems is consistently more (or less) efficient provides prima facie evidence that the conclusion is largely country and/or year and/or bank specific. The models employed in the earlier step, which are consistent with this relevant literature, are hindered by the vanishing degrees of freedom when trying to control for all such factors at once. Moreover, the small number of Islamic banks in any given country further complicates any attempt to fully capture heterogeneity. This casts doubts on the standard practice in the literature of sampling across countries.

Fourth, we use the classification tree results, panel logit models and a wide array of financial structure, macroeconomic, market structure and bank-level characteristics to explain the drivers of the (mis-) alignment of the two banking systems across countries.

Evidence of differences in both efficiency steady states and convergence rates would support the hypothesis that Islamic banks operate a different banking business model. On the other hand, the absence of a significant difference can be taken as an indicator of mimicking behaviour and would favour the hypothesis that the two banking models differ only theoretically and not in practice. Our main findings are as follows. On average, the traditional $\beta$-convergence model finds no significant differences in steady state efficiency and efficiency convergence rates of the two bank types. Thus, Islamic banking practices (at an international level) are not sufficiently different from conventional ones to affect long-run efficiency or convergence, although at various points in time - e.g., episodes of financial distress - shortrun efficiency deviations may exist. Examination of differences in convergence rates by country suggests that convergence is significantly different between the two bank types in certain countries.

The classification trees analysis further reveals that steady state efficiencies and convergence rates vary both by bank type and by country in certain cases. For example, Islamic and conventional banking in Malaysia are indistinguishable in terms of steady state efficiency and convergence rates, whereas differences between the two banking systems are more evident in some of the Middle East countries. The cross-country alignment of the two banking systems is positively related to financial depth, transparency in business, stability in the economic environment and concentration. Aligned banking systems are associated with diversified income sources, higher liquidity, profitability and financial stability.

Our paper offers four main contributions. We provide the first formal approach that goes beyond a simple efficiency analysis by comparing efficiency dynamics (i.e., steady states and 
convergence rates) between Islamic and conventional banks. Second, we use a random parameter model, which is novel in this context and allows for increased heterogeneity in the efficiency steady states and convergence rates across banks. Third, we provide a country classification of the two bank types by steady state efficiency and efficiency convergence. This is important as it groups the countries where the two banking systems are more aligned. Thereby we provide novel results that bring further insights regarding the differences between the two banking business models and underlying corporate structure. Furthermore, our findings tally with the recent trend in the literature suggesting that the practices of the two bank types are converging (Olson and Zoubi, 2017). Fourth, and to the best of our knowledge, this study is the first to highlight the drivers behind the (mis-)alignment of Islamic and conventional banks from a cross country perspective.

In summary, our analysis extends the conventional paradigm adopted by most studies and which focuses on explaining the differences between the two banks types based on the business model and focuses instead on highlighting the role of country specific economic and financial indicators as drivers to such differences. Moreover, we also outline that differences with respect to efficiency and convergence are only significant in the short-run and that the two systems are pretty much aligned in the long-run. As such our results are important from both an operational and a regulatory perspectives.

The remainder of the paper is organised as follows. Section 2 provides background information, reviews the relevant literature and presents the theoretical framework. The methodological approaches employed to address our stated questions are presented in section 3 , while the data are presented in section 4 . Results and discussion are presented in section 5. Finally, we draw conclusions and policy implications in section 6.

\section{Background information, related literature and theoretical framework}

\subsection{Background information}

Islamic banking refers to practices that are commensurate with Shariah, where commonly acknowledged prohibitions include: debt interest payment, complex derivative products, short-selling, gambling, and dealing with alcohol and tobacco. Islamic finance engages with equity-based services (Mudarabah) in which an investor and an entrepreneur enter into a joint profit-sharing venture. Murabahah is a cost-plus-profit sale. With Ijarah, a bank leases an asset charging set fees. Among a variety of general features that investigations purport to show, are that Islamic banks: are more profitable (Hasan and Dridi, 2011), feature superior asset quality and capitalisation (Beck et al., 2013b); share a similar risk profile with their conventional counterparts (Abedifar et al., 2013; Baele et al., 2014; Čihák and Hesse, 2010; Pappas et al., 2017); and exhibit higher technical efficiency (Johnes et al., 2014). ${ }^{2}$ That is not to say that Islamic banks are not subject to economic shocks, but the claim is that these are more muted (Di et al., 2017; Olson and Zoubi, 2017).

\footnotetext{
${ }^{2}$ We direct you to Abedifar et al., (2015), Alzahrani and Megginson (2017), Kabir Hassan and Aliyu (2017) for some interesting surveys of Islamic banking literature.
} 
It is argued that the distinct Islamic profile enhances diversification opportunities for investors, see for example Sorwar et al., (2016), Alexakis et al., (2017b) and Akhtar et al., (2017). Conversely, some Islamic stocks may be adversely affected by religious restrictions on stock trading (Alhomaidi and Kabir Hassan, 2017). Moreover, Islamic banks are particularly engaged with the development and economic welfare within low income countries (Abedifar et al., 2016). In part, this may be explained by their relatively higher liquidity creation (Berger et al., 2017). ${ }^{3}$

In terms of corporate governance, Islamic banks typically maintain a Shariah Supervisory Board (SSB) which, working alongside a Board of Directors, is considered the "Supra Authority" (Choudhury and Hoque, 2006). Related research finds that a large SSB is associated with enhanced financial performance (Farag et al., 2017; Mollah and Zaman, 2015) and acts as a protective cushion against risk (Mollah et al., 2017a, 2017b; Pappas et al., 2017; Uddin et al., 2017). However, the dual board structure of Islamic banks is also known to impair their cost efficiency (Uddin et al., 2017).

\subsection{Related literature}

Studies of banking efficiency fall into two general categories. The first comprises studies which estimate banking sector efficiency at specific points in time, and possibly also examine, in a second stage, the determinants of efficiency. The second category contains studies which examine the existence and speed of efficiency convergence, and hence are more focused on the dynamics underlying efficiency convergence. We consider each of these in turn.

A vast literature is devoted to the measurement of banking efficiency with early reviews including Berger and Humphrey (1997), Berger and Mester (1997), Brown and Skully (2002), Casu et al., (2004), while a more recent synthesis can be found in Fethi and Pasiouras (2010). A growing literature that compares the efficiency of Islamic and conventional banks provides only mixed evidence regarding the efficiency of the two bank types. Some of these studies find no significant difference between the two bank types (El-Gamal and Inanoglu, 2005; Grigorian and Manole, 2006; Hassan et al., 2009; Mohamad et al., 2008), while other studies find that Islamic banks are significantly more efficient than conventional banks (AlJarrah and Molyneux, 2006; Al-Muharrami, 2008; Olson and Zoubi, 2008). But there is also evidence (including the most recent studies) that Islamic banks are significantly less efficient than conventional ones (Abdul-Majid et al., 2011a, 2011b, 2010; Kamarudin et al., 2014; Mobarek and Kalonov, 2014). These conflicting findings are in part attributed to the sample selection deficiencies that studies in this field suffer from. In particular, in an attempt to boost the sample size, a customary practice is to feature a number of disparate countries, where banks can be expected to face different economic conditions, banking and accounting regulations, as well as practices.

Banking efficiency studies that undertake a second stage analysis indicate that efficiency per se is an important aspect alongside other bank characteristics such as size, composition of

\footnotetext{
${ }^{3}$ More research is required in the link between liquidity creation and real economic activity; the limited evidence suggest a positive link between liquidity creation and GDP/capita (Berger and Sedunov, 2017).
} 
assets, risk, liquidity and market structure/macroeconomic variables that affect banking performance (Beck et al., 2013; Berger and Mester, 1997; Dietsch and Lozano-Vivas, 2000; Hasan and Dridi, 2011; Koutsomanoli-Filippaki et al., 2009; Miller and Noulas, 1997; Staikouras et al., 2008; Yudistira, 2004).

Measuring efficiency convergence typically employs two approaches: the $\beta$ - and $\sigma$ convergence models borrowed from the growth literature (Sala-i-Martin, 1996) and the dynamic factor models (Kose et al., 2012; Phillips and Sul, 2009, 2007). A key hypothesis is that increasing global financial integration has led to banking efficiency convergence in a world-wide setting and there is plenty of evidence in support of such convergence across time (Andrieş and Căpraru, 2014; Fung, 2006; Gallizo et al., 2016; Kasman and Kasman, 2013; Mamatzakis et al., 2008; Rughoo and Sarantis, 2014; Weill, 2009; Zhang and Matthews, 2012).

In the context of Islamic and conventional bank efficiency convergence little research has been done, even though this is a well-researched topic within the EU and US. In particular, little interest has been shown in the steady state values that are derived from efficiency estimation models. One exception (Fung, 2006) highlights that bank efficiency convergence of US bank holding companies is conditional upon their initial differences in X-efficiency. The relatively few studies devoted to Islamic banking do not deal with efficiency convergence. Yet, convergence becomes increasingly important as Olson and Zoubi (2017) find that the two banking systems converge in terms of profitability, but not in terms of risk. As Islamic banks work alongside conventional banks there is every reason to expect comparable efficiency convergence dynamics between the two bank types. This is worth investigating as a similar pattern would indicate that the two business models are closely related despite of being argued otherwise elsewhere (Khan, 2010). Different conversion patterns confirm the existence evidence that two entities are indeed different. These are the gaps in the literature which we aim to fill.

\subsection{Theoretical framework}

The dynamics of efficiency are particularly important in the context of competitive advantage. Based upon resource-based theory (Chen et al., 2015) relative profitability performance correlates with differences in efficiency (Demsetz, 1973; McGahan and Porter, 1999). Such efficiency differences might arise from differences in technology, experience or the business model. If efficient production techniques can be imitated by rivals, efficiency differences should not persist. Where differences do persist, this might indicate an inability to identify (or an unwillingness to copy) the operations of rivals. The terminology is "uncertain imitability” (Lippman and Rumelt, 1982).

The pivotal role of efficiency in banking has been well-documented in studies examining the interlinks between capitalisation, bank risk and competition (Altunbaş et al., 2001; Dong et al., 2017; Fiordelisi et al., 2011; Gonzalez, 2009; Kwan and Eisenbeis, 1997; Schaeck and Cihák, 2014). Recent studies show a negative relationship between competition and bank stability (Anginer et al., 2014; Goetz, 2018). Given the association between low values of efficiency and higher bank risk (Berger and DeYoung, 1997; Kwan and Eisenbeis, 1997), 
competition incites banks to increase efficiency, strengthen performance and survive. Indeed, the role of efficiency may be catalytic (Beck et al., 2013a; Schaeck and Cihák, 2014). The speed of convergence in the presence of efficiency differences could be taken as a signal of competitive advantage; with slow convergence, competitive advantage is maintained for longer. In an ideal world, any bank would optimise its business model to attain long-run efficiency. Several factors (relating to economic conditions, operation and regulatory frameworks) may impede this process, and therefore affect both the convergence rate and the level of long-run efficiency of the bank. Differences in convergence rates (as well as the steady state efficiency levels) might arise because business practices, objectives and underlying principles differ.

There is no clear theory underlying the similarities/differences between the convergence rates of Islamic banks to their conventional counterparts. But these may be expected between the two bank types for a number of reasons.

First, there may be differences between the theoretically envisaged Islamic banking model and what is observed in reality. For instance, the cornerstone of Islamic banking is equity finance (El-Hawary and Grais, 2003), with profits and losses shared between the contracted parties according to some pre-determined ratio (Usmani, 2004). Yet, equity financing may constitute a small percentage of a typical Islamic bank's asset portfolio (El-Gamal, 2006; Khan, 2010; Zaman and Movassaghi, 2002). Instead, fee-based financial products are the norm, where an "implicit" interest rate is charged that is often highly correlated with the "explicit" interest rate observed in the conventional banking sector (Hussan and Masih, 2014).

Second, the extent of compliance with Islamic principles tends to vary by bank size, product offerings and demographics. Products, such as Islamic microfinance, are more common in the Far East, whereas real estate finance is more dominant in the Gulf Cooperation Council (GCC) region. Therefore, differences in steady state efficiency and efficiency convergence rates might be expected within the Islamic banking sector; hence blurring distinctions between Islamic and conventional banks.

Third, over time we would expect financial integration to increase worldwide through common regulatory frameworks (such as the Basel Accord), ${ }^{4}$ trade and monetary unions (for example the European Union) and an ever-increasing global banking presence (HSBC, for example, has branches in 80 countries). Thereby efficiency is more likely to become prominent on banks' agenda and convergence is expected to take place (Fiordelisi et al., 2011).

Fourth, regulation and supervision of Islamic banking remains challenging at an international level. For example, regulators need to incorporate the peculiarities of Islamic banking, most notably with respect to capitalisation and liquidity management, into their operations, while ensuring a level playing field between Islamic and conventional banking (Song and Oosthuizen, 2014). Some countries document important improvements at this front but

\footnotetext{
${ }^{4}$ Delis et al., (2011) highlights the contribution of such international organisations to the financial development of transitional economies.
} 
Islamic banking expands to new countries, each with unique peculiarities. Hence, crosscountry differences with respect to accounting standards, regulatory and supervisory frameworks, licensing requirements and Shariah board authority impedes standardisation further contributing to the efficiency gap.

Fifth, unique aspects of the Islamic business model could affect the efficiency gap and its dynamics. The Islamic banking model allows risk to "pass-through" from the asset to the liability side, thereby limiting the impact of adverse shocks on their solvency (Beck et al., 2013b). Islamic financial products require the management of an inventory of assets (e.g., real estate, commodities), a task of increased complexity, known to impact efficiency (Ariss, 2010; Beck et al., 2013b). Shariah restrictions can increase asset concentration amidst limited hedging and risk management capabilities (Elnahass et al., 2014; Saeed and Izzeldin, 2016). Islamic banks may have limited course of action with regards to late payments and/or default (Baele et al., 2014; Song and Oosthuizen, 2014). The increased loyalty of religious clients may reduce pressure on Islamic banks to perform (Abedifar et al., 2013).

In summary, both efficiency and the ability to swiftly revert to the steady-state (i.e., efficiency convergence), are important aspects to the Islamic banks long-term survival and/or expansion.

\section{Estimation framework - efficiency and convergence}

An implicit assumption underlying most efficiency studies is that all the banks under examination are fully synchronised. Yet, banks may face diverse - and react differently to idiosyncratic and systemic shocks. Hence, they might be at different stages on their path towards equilibrium efficiency. To allow for this we generalise the assumption of homogenous response to shocks by first estimating the efficiency of our sample banks and then examining more closely their steady state and convergence patterns. We use three techniques that we detail below.

\subsection{Efficiency Estimation using an $O D F$}

Banking efficiency is typically measured using one of two approaches: a parametric frontier estimation, such as stochastic frontier analysis (SFA) or a non-parametric frontier estimation, such as data envelopment analysis (DEA). Both approaches have been widely adopted within the banking context; see for example Ghroubi and Abaoub (2016), Jackson and Fethi (2000).

In this study, we estimate the ODF using SFA, and apply a translog functional form as it is flexible, easy to estimate and permits the imposition of homogeneity (Coelli and Perelman, 2000) - see Appendix 1 for technical details. Moreover, the SFA estimation allows for stochastic errors and considers the panel nature of our data. We estimate the ODF across all observations, i.e. across countries and across time periods as in for example Gallizo et al., (2016) and Mamatzakis et al., (2008). While it might be argued that different countries observed at different time periods face different production conditions, this is, in fact exactly what the convergence models in the second stage aim to capture. Making allowances for 
these differences at this stage might conceal variations either in steady state efficiency or convergence rate, which might exist because of differences in environment or starting conditions. Moreover, we measure efficiency in a way so as to ensure a level playing field for both bank types. Therefore, we use a production function approach as in Casu and Girardone (2010) in preference to a cost or profit function because Islamic banks may not focus entirely on cost-minimization or profit-maximization. Given that the similarities between the Islamic and conventional banking practices can be both country and time specific, we opt to measure efficiency using an ODF that makes no specific assumptions about optimizing behaviour. A single ODF across all types of banks may be justified on the grounds that there is increasing competition between Islamic and conventional banks as evidenced by, for example, conventional banks establishing Islamic subsidiaries and/or Islamic windows, the availability of Islamic financial products and banks in non-Islamic countries, and the targeting of some Islamic products at all types of customers (Warde, 2000).

The choice of variables qualifying for the distance function is guided by the previous literature (Abdul-Majid et al., 2011a, 2010; Casu et al., 2004; Casu and Girardone, 2004) and data availability. We follow the popular intermediation approach; see for example, Pasiouras (2008). For the choice of inputs and outputs we follow Johnes et al., (2014), using: i) deposits and short term funding $\left(x_{1}\right)$, ii) fixed assets $\left(x_{2}\right)$, iii) general and administration expenses $\left(x_{3}\right)$ and iv) equity $\left(x_{4}\right)$ as inputs to produce: i) total loans $\left(y_{1}\right)$ and ii) other earning assets $\left(y_{2}\right)$. The justification for including these variables in the distance function model is explained in greater detail in Johnes et al., (2014). All monetary variables have been converted to real values using the GDP deflator.

Our efficiency model provides a measure of gross efficiency and makes no distinction between conventional or Islamic banks. Underlying structural differences between the two sectors which might affect steady state efficiency are addressed in the convergence model.

\subsection{Modelling steady state efficiency and convergence}

We utilise the concepts of $\beta$ - and $\sigma$-convergence models (Young et al., 2008) to explore differences in steady state efficiency and efficiency convergence across the two bank types over the sample period. The convergence models used here and in other studies of banking efficiency convergence, see for example Weill (2009) and Casu and Girardone (2010), are adapted from the growth literature (Sala-i-Martin, 1996). The basic $\beta$-convergence model is:

$$
\ln \left(u_{i, t}\right)-\ln \left(u_{i, t-1}\right)=\alpha+\beta \ln \left(u_{i, t-1}\right)+\varepsilon_{i, t}
$$

where $u_{i, t}$ is the measure of efficiency of bank $i$ in time period $t$. The value of the parameter $\beta$ represents convergence (if $\beta<0$ ) or divergence (if $\beta>0$ ) in banking efficiency. The larger is $|\beta|$ the greater is the speed of convergence or divergence. However the $\beta$-coefficient can be negative because of data measurement errors and random shocks rather than because of genuine convergence (Fung, 2006). To ensure that the $\beta$-coefficient signifies real convergence (rather than reversion towards the mean) it must coincide with significant $\sigma$ convergence (Fung, 2006) which is a measure of convergence based on the dispersion of a bank's efficiency around the sector average in a given time period. We therefore estimate $\sigma$ - 
convergence in order to validate our $\beta$-convergence measures are valid. The basic $\sigma$ convergence model is given by:

$$
\Delta w_{i, t}=\gamma+\sigma w_{i, t-1}+\varepsilon_{i, t}
$$

where $w_{i, t}=\ln \left(u_{i, t}\right)-\ln \left(\bar{u}_{t}\right)$ and $\Delta w_{i, t}=w_{i, t}-w_{i, t-1}$. Note that the value of the parameter $\sigma$ can be interpreted in a similar manner to the value of $\beta$.

We estimate a conditional $\beta$-convergence model whereby specific banks (Islamic or conventional) are permitted to have both different steady state efficiency levels and rates of convergence. For robustness, we use a variety of estimation methods including OLS, random effects and system-GMM. We implement a two-step system GMM approach, in line with the empirical applications of Mollah and Zaman (2015) and Casu and Girardone (2010), while following the theoretical underpinnings of Arellano and Bover (1995), Blundell and Bond (1998) and Roodman (2006). As an additional robustness check we allow the value of both $\alpha$ and $\beta$ to vary for each bank in the sample by using a random parameter method of estimation (Swamy, 1970) for equation (1). These estimation methods address the issues of unobserved heterogeneity and endogeneity to differing extents. In particular, the RPM generalises the efficiency convergence framework by allowing each bank to have its own unique convergence dynamics. It is, therefore, better suited to cater for heterogeneous bank samples. This is particularly relevant for the Islamic banks as there are important differences within their sector with regards to bank size, age, financial product focus and Shariah board compliance. More details on models and methods are provided in Appendix 2.

\subsection{Classification trees}

A difficulty in cross-country analysis is to identify precisely the impact of bank type, country specific characteristics and regulation upon the quantity of interest (e.g., efficiency steady state or convergence rate). Traditional estimation methods often pose restrictions, due to the degrees of freedom limitations, when examining differences in the values of $\alpha$ and $\beta$ (see equation 1) by country and type. We therefore use a non-parametric classification tree methodology (see Appendix 3) to identify groups of banking sectors (by country) with similar steady state $(\alpha)$ or convergence $(\beta)$ characteristics. The classification tree method has previously been used in a banking efficiency setting Emrouznejad and Anouze (2010), but has not been applied in the context of steady state efficiency or efficiency convergence.

We apply the classification tree algorithm to the convergence rate $(\beta)$ and steady state efficiency $(\alpha)$ estimates based on the RPM to examine whether there are groups of banks identified that share similarities with respect to efficiency dynamics. Here, we assume that any differences shall conform to the ex-ante Islamic/conventional split for every country. Classification trees can handle various types of control variables (i.e. continuous, categorical and binary), although the dependent variable must be binary. ${ }^{5} \mathrm{~A} \beta$-convergence binary variable is constructed for the full sample and classifies banks into high/low $\beta$-convergence

\footnotetext{
${ }^{5}$ Note that regression trees, in contrast, can handle continuous dependent variables at the expense of more complicated tree structures.
} 
estimates according to a median split. In a similar manner, a steady state binary variable based on $\alpha$ estimated using the RPM is constructed. Our control variables are the bank type (Islamic or conventional) and the country indicator.

\section{Data}

The data are drawn predominantly from the balance sheets and income statements of the Bureau van Dijk Bankscope database for the period 1999 to 2014 and across 23 countries. The countries are: Bangladesh, Bahrain, Brunei, Egypt, Indonesia, Iran, Jordan, Kuwait, Lebanon, Mauritania, Malaysia, Oman, Philippines, Pakistan, Qatar, Saudi Arabia, Sudan, Singapore, Syria, Tunisia, Turkey, United Arab Emirates and Yemen. A small number of observations for missing periods were obtained from the annual reports of individual banks. We finally derive an unbalanced panel of 4,864 bank-year observations for Islamic and conventional banks, with the number of banks ranging from 158 in 1999 to 502 in 2014. Of this total of bank-year observations, 1,089 relate to Islamic banks and 3,775 relate to conventional banks. There is clearly a large difference between the number of Islamic and conventional banks. While nearly $25 \%$ of our observations relate to Islamic banks this is similar or higher than in previous studies (Abdul-Majid et al., 2010; Al-Jarrah and Molyneux, 2005; Beck et al., 2013b; Čihák and Hesse, 2010; Srairi, 2010). In line with Beck et al., (2013), we have winsorized at the $1^{\text {st }}$ and $99^{\text {th }}$ percentiles. Table 1 presents the distribution of bank observations by operational mode and country. Every country has at least one bank of each type over the time period covered.

\section{Table 1 here}

Table 2 displays the mean values of the inputs and outputs of the ODF by bank type (panel a) and the number of bank observations by type and country (panel b). While Islamic banks are typically smaller than conventional banks in terms of deposits, loans and other earning assets, they are remarkably similar in terms of administrative expenses and are larger in terms of fixed assets. The relatively large mean administrative expenses for Islamic banks is reflective of the extra costs related to the Shariah board; while the high value of mean fixed assets follows the collateral requirements of many Islamic banking products; hence banks would typically have tangible assets (e.g., buildings, commodities) at their disposal for such use.

\section{Table 2 here}

\section{Results and Discussion}

\subsection{Parametric estimation of efficiency using an $O D F$}

Figure 1 presents the efficiency scores derived from the first stage stochastic ODF, ${ }^{6}$ from which it appears that conventional banks have a higher efficiency than Islamic banks (AbdulMajid et al., 2011a, 2010; Johnes et al., 2014; Srairi, 2010). This difference is significant at the $10 \%$ significance level for the sample as a whole and for all individual years apart from 2011. Whether these efficiency differences between Islamic and conventional banks at given

\footnotetext{
${ }^{6}$ The estimated parameters of this distance function are available on request.
} 
points in time represent a difference in long term or steady state efficiency will be investigated in the second stage convergence analysis.

Figure 1 here

\subsection{Steady state efficiency and efficiency convergence}

\section{a) OLS, random effects and system-GMM estimation}

Table 3 reports parameter estimates of absolute and conditional $\beta$-convergence models using, respectively, OLS, random effects (RE) and system-GMM estimation methods. ${ }^{7}$ The parameter estimates are similar across all estimation methods. The significance of the $\sigma$ coefficient in the associated $\sigma$-convergence model (see Appendix 4 for full $\sigma$-convergence results) confirms that the estimates of $\beta$-convergence in these models can be considered to be genuine, rather than reversion to the mean; see also Casu and Girardone (2010).

\section{Table 3 here}

A first inspection of the estimated parameters of models in columns I, IV and VII provide interesting reading. The (exponentiated) estimated intercepts suggest that all banks are converging at a steady state efficiency value of around 0.92 to 0.95 , depending on estimation method. While there is no obvious link between steady state efficiency and financial development (as proxied by stock market capitalisation), the three countries with the markedly lowest steady state efficiency in the sample (see Figure 2), namely Syria, Brunei and Mauritania with a $3.85 \%$ average percentage point difference to Egypt, do not feature a stock market. The estimated $\beta$ coefficient ranges between -0.283 and -0.442 and is comparable with estimates reported in previous studies using EU and US banking data, suggesting comparable efficiency convergence dynamics in the banking systems of our sampled countries.

Figure 2 here

The slope and intercept dummies for bank type show no statistical significance across all models (columns II, V and VIII). The same conclusion is reached when country intercept and slope effects and time intercept effects are considered (columns III, VI and IX). The result suggests that Islamic and conventional banks are not different in terms of long-term (steady state) efficiency and convergence (to the steady state) rates. This suggests a close alignment of the two bank types, which may be in part attributed to Islamic banks offering products that are closely aligned to those of the conventional. This could be driven by similarities in the financial products required by the clientele of either bank type. There is also the need to comply with international accounting standards, banking regulation frameworks and product offering (Martynova and Renneboog, 2011). This finding offers an affirmation to the literature contradicting any differences between the two bank types (see also section 2). Therefore, any differences in efficiency observed in the first stage (figure 1) of the analysis,

\footnotetext{
${ }^{7}$ Note that the system-GMM estimations satisfy the conditions that there is significant AR(1) serial correlation, no AR(2) serial correlation and high Sargan/Hansen test (Casu and Girardone, 2010).
} 
and which are also echoed in a substantial part of the literature, are merely short-term, transitory ones.

Figure 3 presents the steady state efficiencies over time. The countries in the sample have been through several instances of financial distress and instability, most notably the late 1990s Far East Crisis, the 2003 Iraq War, the 2005 crash of the Saudi Arabian stock market, and the 2008 global financial crisis. The patterns suggest that such events are negatively associated with steady state efficiency.

Figure 3 here

\section{b) RPM estimation}

Table 4 presents the average estimated coefficients of the RPM model (see equation A2.2) and figure 4 presents their kernel densities by bank type. The average steady state efficiency is 0.90 with no significant difference between Islamic and conventional banks. Likewise, the average convergence rate is -0.554 , again with no significant difference between Islamic and conventional banks. These (average) results are in line with those of the alternative estimation methods reported in table 3. Thus, once the individual circumstances of each bank are accounted for (i.e., each bank is permitted to have its own steady state efficiency and convergence rate) there appears to be no significant difference between Islamic and conventional banks either in terms of their steady state efficiency or the speed with which they converge to it. Our a priori clubs (Islamic and conventional) are thus far not confirmed empirically.

However, the kernel densities suggest that the efficiency convergence dynamics of the two bank types may still be different, albeit country factors may be concealing such variations. Here, we want to elaborate on this rather crucial point. Suppose that the average efficiency steady state of conventional banks in our sample is 0.93 . All the regression-based techniques we have deployed up to this point are valid for the average efficiency steady state of Islamic banks, while potentially allowing for country and time effects. However, such (parametric) techniques cannot allow for interactions between country, time effects and bank type due to the vanishing degrees of freedom. Therefore, these models are incapable to allow for the fact that in some countries Islamic banks may have a higher efficiency steady state than conventional banks while in others the opposite may be true. The RPM estimation offers a way to take this into account, but when the results are averaged, for reporting purposes as in table 4 for example, this information is lost. Instead, kernel density plots of the estimated parameters allow for the extraction of such information. Kernel densities by country are even better in this respect and show precisely that the Islamic banks are not always (i.e., in every country) inferior to conventional banks. ${ }^{8}$

Therefore, before concluding that the two banking models are truly similar, we need to explore the possibility that country differences are concealing variations between the two bank types. The section below presents the results of the classification trees approach.

\footnotetext{
${ }^{8}$ These kernel densities by country are available upon request.
} 
Table 4 and Figure 4 here

\subsection{Classification trees}

Table 5 presents goodness-of-fit statistics for the classification trees, in line with those reported in Delen et al., (2013), Irimia-Dieguez et al., (2015), West (2000), namely accuracy, area under curve (AUC), expected misclassification cost (EMC), and pseudo R-squared (see also Appendix 3). These goodness-of-fit statistics show that the majority of the explanatory power comes from country factors, not the bank type. However, using both country and banking type information the classification works the best.

\section{Table 5 here}

Table 6 presents the clubs generated by the classification tree approach based on steady state (Panel A) and $\beta$-convergence according to bank type and country. The upper (lower) part of the table represents the high (low) steady state and $\beta$-convergence groups, respectively. Each panel lists the Islamic and conventional banking system of each country and the intersection region. It is the intersection region that provides the most interesting conclusion as it identifies those countries for which the two banking systems are similar. Figure 5 presents an optical illustration of Table 6 contents using Venn diagrams.

Table 6 and Figure 5 here

The classification tree results of Table 6 show clear evidence as to why the parametric approaches of the previous steps fail to identify any differences in steady state efficiency and convergence rate. Results vary by country, for instance in some countries, the Islamic banks are the ones exhibiting the highest speed of convergence; in other countries, it is the conventional ones. In addition, disparities in the initial conditions of banks in terms of economic and financial development of the country in which they are located, and the implementation of policies and reforms across countries, mean that banks operating therein may have different steady state efficiency levels as observed in panel A. In some countries, the two banking systems are indistinguishable from one another in terms of steady state efficiency and/or convergence speed; these lie in the intersection of areas in panels A and B of table 6 respectively. A few notable examples are discussed below.

In Malaysia, the two bank types under investigation are indistinguishable in terms of the speed of the steady state efficiency and convergence. In contrast, banks in Jordan belong to different classifications, with conventional (Islamic) banks exhibiting low (high) steady state and high (low) convergence rate. This finding is driven by two reasons. First, in Malaysia, it is common practice for Islamic and conventional banks be part of a bank holding company, thereby sharing knowhow, experience and clientele. In contrast, Islamic banks in the MiddleEast cannot be part of a bank holding company owing to regulations that prohibits Islamic banks from sharing any ties with conventional financial institutions, hence expertise and other resources cannot be shared (Song and Oosthuizen, 2014). Furthermore, Islamic banks in Malaysia adopt financial instruments, whose Shariah conformity has been challenged in the 
Middle-East and as a consequence these are not valid for use therein. ${ }^{9}$ This allows Malaysian banks to enhance their marketability and outreach of their Islamic Finance banks and related outlets. In contrast, the Middle-East (and particularly the GCC) comprises a dominant, concentrated, mainly domestic banking sector and traditional loan-taking/deposit-making activities constitute the bulk of operations there. As such, the banking portfolio of these countries features large exposures in real estate, infrastructure and household financing, while securities investments are limited (Al-Hassan et al., 2010).

Pakistani Islamic banks belong to a low steady state/low convergence club, while the high steady state/ high convergence club is populated by the conventional banks. This apparent underperformance of Islamic banking may be linked to the history of this institution, with Pakistan being one of the (very) few countries that had opted in the past for a pure Islamic banking model, and which was subsequently abandoned due to implementation problems. ${ }^{10}$

The above results highlight the usefulness of the classification trees in bringing out the differences in a composite financial system, where the efficiency dynamics of multiple banking systems are not always clear cut. ${ }^{11}$ The fact that there is no common equilibrium average efficiency level for Islamic and conventional banks across countries may give evidence of a dual-banking model (Zhang and Matthews, 2012). Conversely the existence of a common equilibrium average efficiency level for the two bank types may give evidence of a single banking model. In the latter case, the country would appear in the intersection of the graph. Drivers of this distinction, albeit latent, may be linked to country-specific characteristics, interpretations of the Islamic banking model and the degree of substitution between the two banking systems on behalf of its clientele.

\subsection{Bank type alignment, characteristics and economic indicators.}

One of our key findings in the previous section has been that the countries that lie within the intersection of figure 5 have the most aligned banking systems. This finding is interesting and merits closer investigation for several reasons. From a policy perspective, these banking systems are arguably less challenging as the two bank types may be viewed as sufficiently similar not to warrant different policy actions; one-size-fits-all type of policies should be most effective here. Policies, regulatory and supervisory practices of these systems may act as paradigms to other, particularly newer country-adopters of Islamic finance (Mejia et al., 2014; Song and Oosthuizen, 2014); see Gelbard et al., (2014) for Islamic finance in SubSaharan Africa challenges. By contrast, such policies in the countries outside of the

\footnotetext{
${ }^{9}$ Certain financial instruments used in Malaysia, quite notably Bai Bithaman Ajil (BBA) that is utilised as a buy-sale property instrument, are not considered Shariah-compliant in the Middle-East. Additionally, the Securities Commission of Malaysia (SCM) has higher tolerances on the non-Shariah sources of income for Shariah-compliant firms (Usmani, 2004).

${ }^{10}$ During the $80 \mathrm{~s}$ and $90 \mathrm{~s}$ Pakistan was operating on a non-interest, Islamic banking model, which faced several implementation issues and was subsequently used in parallel to the conventional banking since 1999 . The other two countries being Sudan and Iran; Iran still operates a pure Islamic banking model, albeit it has recently allowed for conventional foreign bank branches to open in special economic free zones.

${ }^{11}$ Traditional techniques such as regression analysis would require a large number of degrees of freedom. Statistical significance tests are also not useful here given that they are either bivariate or require an $a$ priori assumption on the banking system groupings.
} 
intersection might contribute to the performance gap between the two bank types. As such and from an investor perspective, it is useful to know how the two banking systems compare in countries that fall within / outside the intersection.

In this section, we seek to identify the salient features that characterise the banking systems that lie within the intersection. Table 7 compares background information on the financial structure, macroeconomic environment, market structure and bank specific information ${ }^{12}$ for those banking systems that lie inside the intersections of both graphs of figure 5 (steady state and convergence), and those that lie outside. We refer to the former as Fully Aligned (FA) and the latter as Not-Fully Aligned (NFA).

\section{Table 7 here}

An inspection of Table 7 suggests that there are significant differences between the two groups of banking systems, and these are primarily manifested within the financial structure, macroeconomic and market structure environment. The financial structure variables are suggestive of more pronounced differences with respect to financial depth than financial access. A comparison of the FA banking systems to the NFA ones finds the former to mobilise significantly more domestic credit to private sector, have a more developed insurance industry, while foreign banks are more active in loan generating/deposit taking business. The macroeconomic and market structure environment shows lower inflation rates, higher contribution from trade to GDP and a more concentrated banking system. Higher transparency, less bureaucracy and a more competent legal environment is evidenced in the FA group. The banks in the two groups are comparable in terms of profitability, but the ones in the FA group have higher financial stability (z-score), more diversified operations (Income diversity), and higher liquidity (Net Loans/Total Assets).

In a subsequent step we estimate the following panel robust logit model.

$$
Z_{i}=\mu_{0}+\theta X+\zeta M+\varepsilon_{i}
$$

where $Z$ is a binary variable that takes the value 1 for all banks in the FA group; zero otherwise. The explanatory variables include bank-specific information (denoted as $X$ ) and macroeconomic, market structure and financial development indicators (denoted as $M$ ). Several models are estimated that allow for an increasing number of control variables and allow for fewer similarities between the two bank types. In particular, Model I allows for financial structure, macroeconomic and market structure variables, while Model II caters for bank-specific characteristics. Models III and IV capture the distinction between Islamic and conventional banks by allowing for interaction terms. We use a stepwise algorithm that maximises the goodness of fit. Table 8 presents these results.

\footnotetext{
${ }^{12}$ Similar variables are used in Bertay et al.,( 2013).
} 
Table 8 here

A cursory inspection of the results suggests that country level variables (macroeconomic, market structure and financial development) have the largest explanatory power. This is verified by the fact that around $83 \%$ of the explanatory power of Model II comes from country level variables, and only the remaining is attributed to bank-specific factors. This is to be expected as such variables affect all the institutions in the country. The banking systems under the FA group have a significantly higher business disclosure index, suggesting that business practices are more transparent therein. Additionally, the financial depth in the FA group is also higher as verified by the positive and significant domestic credit to private sector and bank credit to bank deposits variables; thus warranting enhanced opportunities for company financing through higher financial development. On average, lower inflation rates characterise the FA group, corroborating further on the importance of a stable economic environment. Concentrated banking systems are more evident in the FA group, as verified by the positive and statistically significant Hirschman-Herfindahl indices.

Bank-level characteristics are also important. In particular, the average bank in the FA group has a well-diversified source of income (Income Diversity), is typically smaller (Total Assets), more leveraged (Equity/Assets), more liquid (Net Loans/Total Assets), more profitable (Return on Equity) and are more financially stable (z-score) than the average bank of the NFA group.

Compared to Models I and II respectively, Models III and IV show that the response of the two banking systems may deviate to similar changes in the underlying metrics. For example, a stable economic environment, proxied by lower inflation rates, tends to align the practices in Islamic and conventional banking systems; which manifests to a more homogenous financial system in that country. A similar conclusion is reached for financial depth. By contrast, alignment in the two banking systems is affected contrarily with respect to the Business Disclosure Index and the Legal Rights Index, potentially highlighting the different requirements of either bank type. Therefore, a country's improvement with regards to these metrics needs to ensure a close alignment between these characteristics. Differentiated responses between the two bank types exist with respect to bank-specific characteristics too. For example, with respect to the average bank size. Large imbalances between banks constitute a challenge for a closely aligned financial system. This bank size effect is particularly relevant for Islamic banks as it affects business practices in complex ways. For example, large Islamic banks behave similarly to conventional banks (Abedifar et al., 2013), while the smaller of Islamic banks tend to perform better and bear less risk (Beck et al., 2013b; Čihák and Hesse, 2010).

\section{Conclusion}

Measuring and comparing banking efficiency has received much attention, but few studies focus upon the dynamics of efficiency (steady state and convergence) and none compare 
conventional and Islamic banks. In this paper, we compare and contrast estimates of steady state efficiencies and efficiency convergence rates of Islamic and conventional banks. With an extended dataset spanning a decade and a half (1999 to 2014) and covering 23 countries, we obtain estimates of bank efficiency scores using stochastic frontier analysis.

To address steady state efficiency and efficiency convergence, we import the concept of $\beta$ convergence from the growth literature. This is a familiar concept in the context of banking in economic unions. We obtain estimates of the convergence rate using OLS, random effects, system-GMM and random parameter model techniques, the last of which is a novel feature of this paper.

Using the $\beta$-convergence model, our estimates using OLS, random effects and system-GMM finds no significant differences exist between the two bank types in terms of steady state efficiency and convergence efficiency. This result is confirmed when the random parameter estimation method is used.

To identify clubs of countries and banking sectors with similar characteristics, we adopt a classification trees framework: a multi-dimensional separation procedure, which circumvents the vanishing degrees of freedom faced by parametric techniques. Classification trees show that the distinctiveness of Islamic and conventional banking (in terms of efficiency steady state and convergence) varies across countries. For example, in Malaysia we observe similar practice for the two bank types; but in Jordan the distinction is marked.

To examine the drivers behind the alignment of the two banking systems, we use a panel logit estimation and a wide array of bank-specific, macroeconomic, market structure and financial development indicators. We find that the more financially aligned systems are characterised by financial depth, transparency in business, stability in the economic environment and concentrated banking systems. Individual banks operating within aligned banking systems have more diversified sources of income, higher liquidity, profitability and financial stability.

Our research clearly identifies countries where the banking sectors are distinct (in terms of steady state efficiency and the speed with which banks converge to it) and those where they are similar. Thus, our findings inform the debate over the claim that Islamic banks generally mimic conventional banks. That similarities exist only in some countries suggests that behaviour may not be attributable to mimicking but to other factors such as regulatory / corporate, economic as well as bank-specific characteristics. Regulators and judicial authorities might be tasked to devise mechanisms and platforms that account for the identities of the two banking models. Future work should attempt to underpin our findings by looking into other factors such as demographic, educational, cultural, business, governance and financial screening practices. 
Figure 1: Evolution of efficiencies over time and by bank types

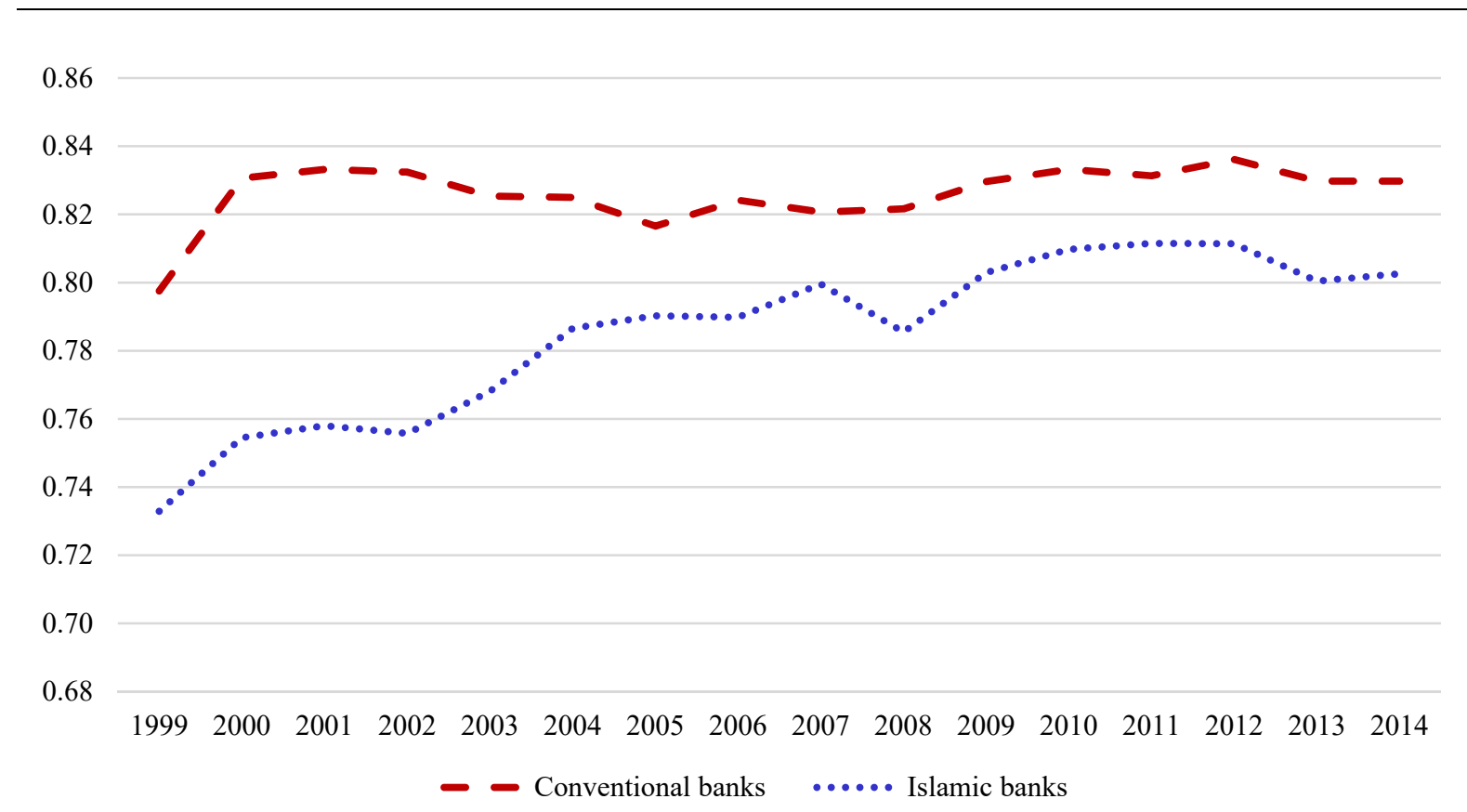


Figure 2: Steady state efficiencies and convergence rates by country

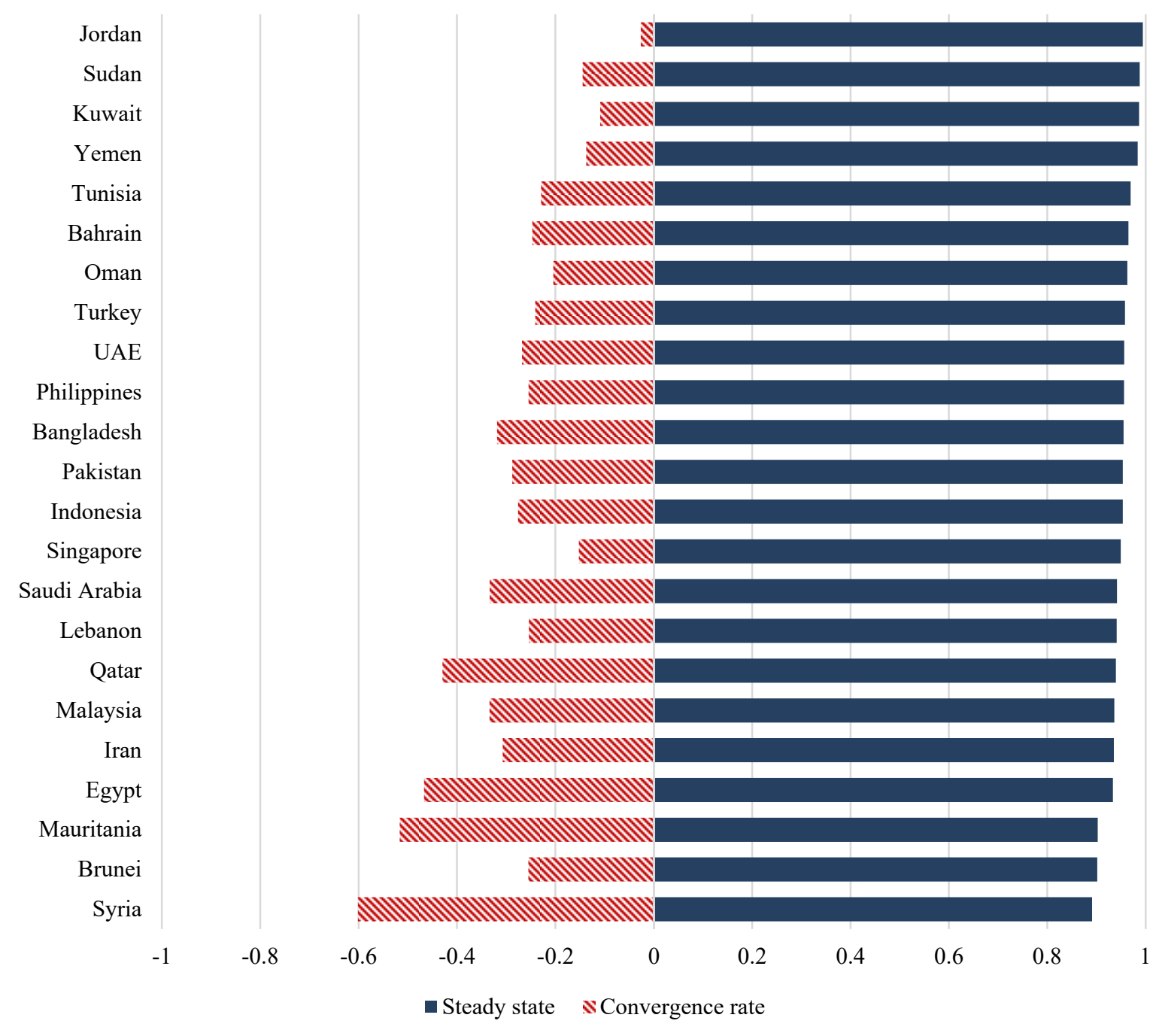

Notes: The figure is based on the results of column III in Table 3. 
Figure 3: Steady state efficiencies over time

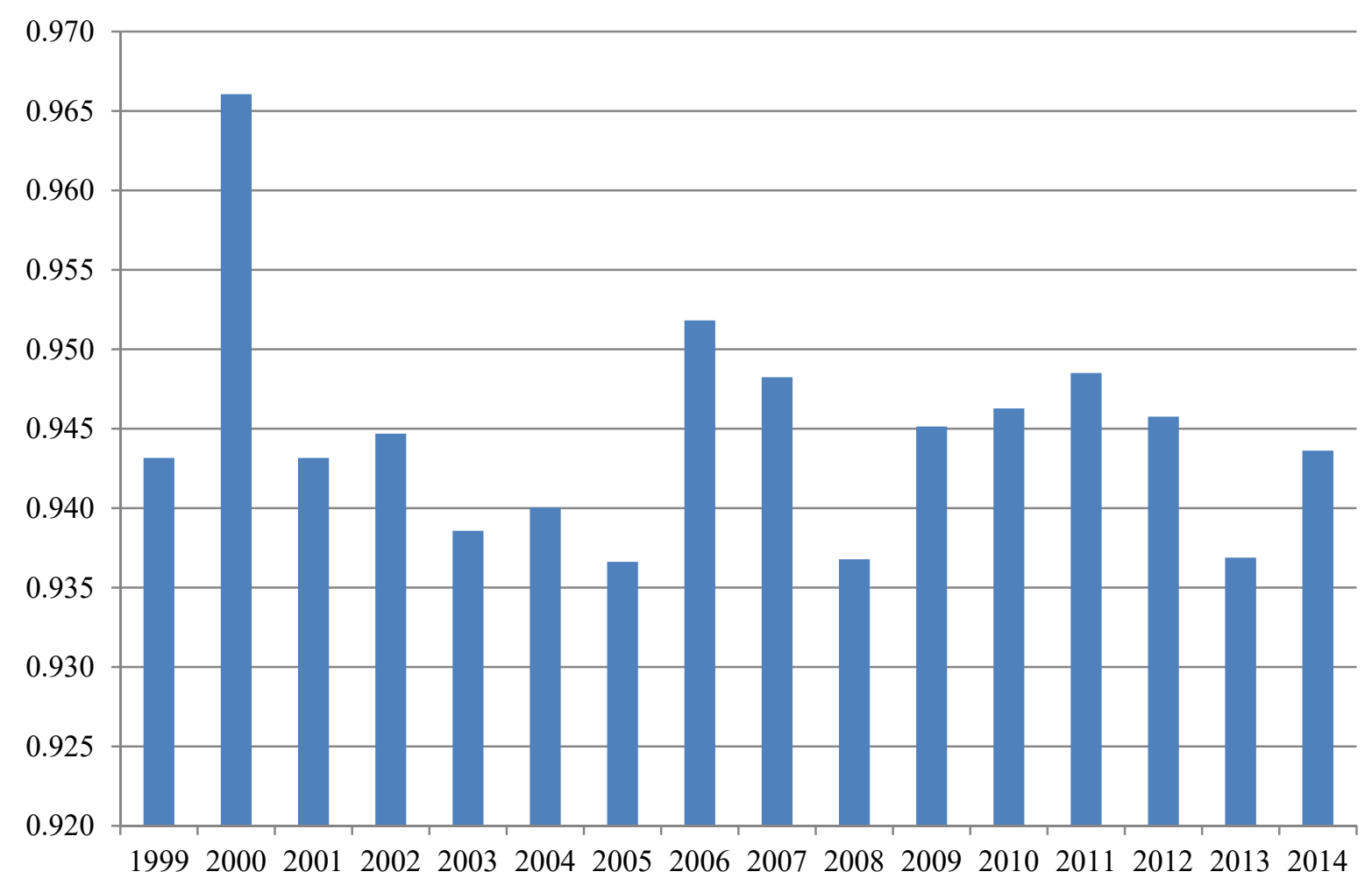

Notes: The base year is 1999. The figure is based on the results of column 3 in table 3 . 
Figure 4: Kernel density plots for convergence rate $(\beta)$ and steady state $(\alpha)$
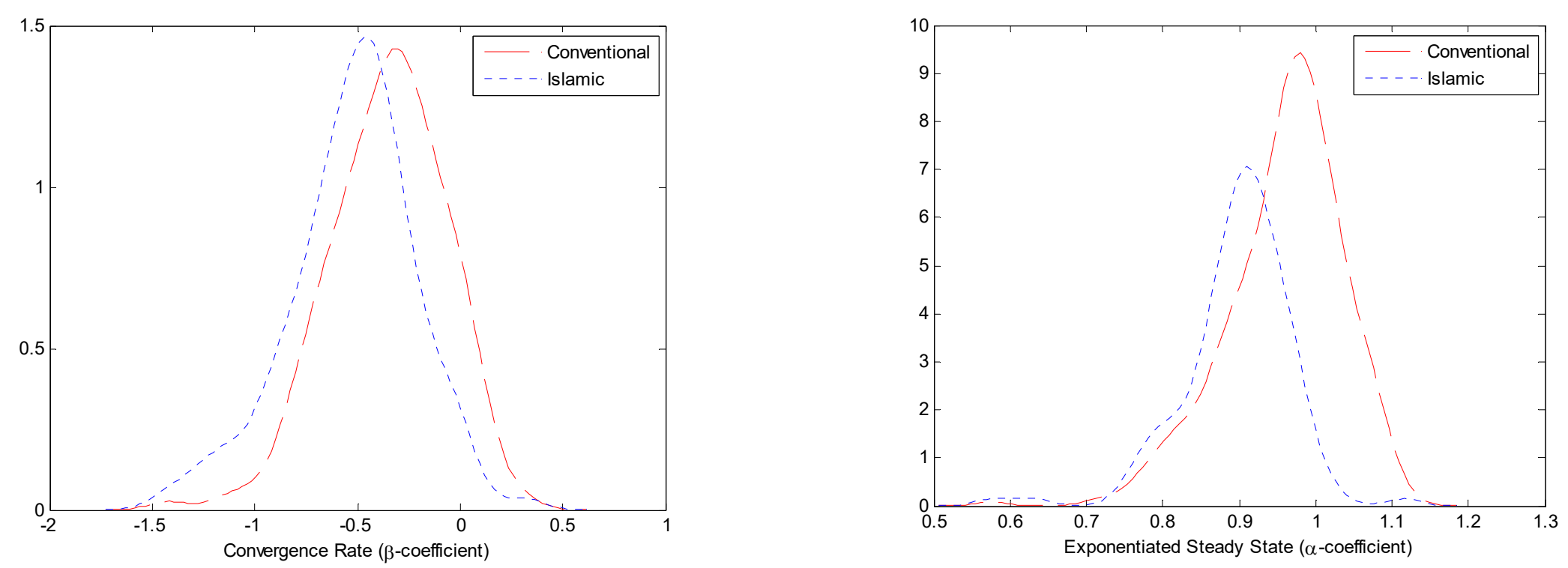

Notes: The figure shows the kernel density plots for the convergence rate ( $\beta$ ) and exponentiated steady state $(\alpha)$ estimates from the RPM model for conventional and Islamic banks. 
Figure 5: Steady State and Convergence Rate Classifications

Panel A: Steady State

Conventional

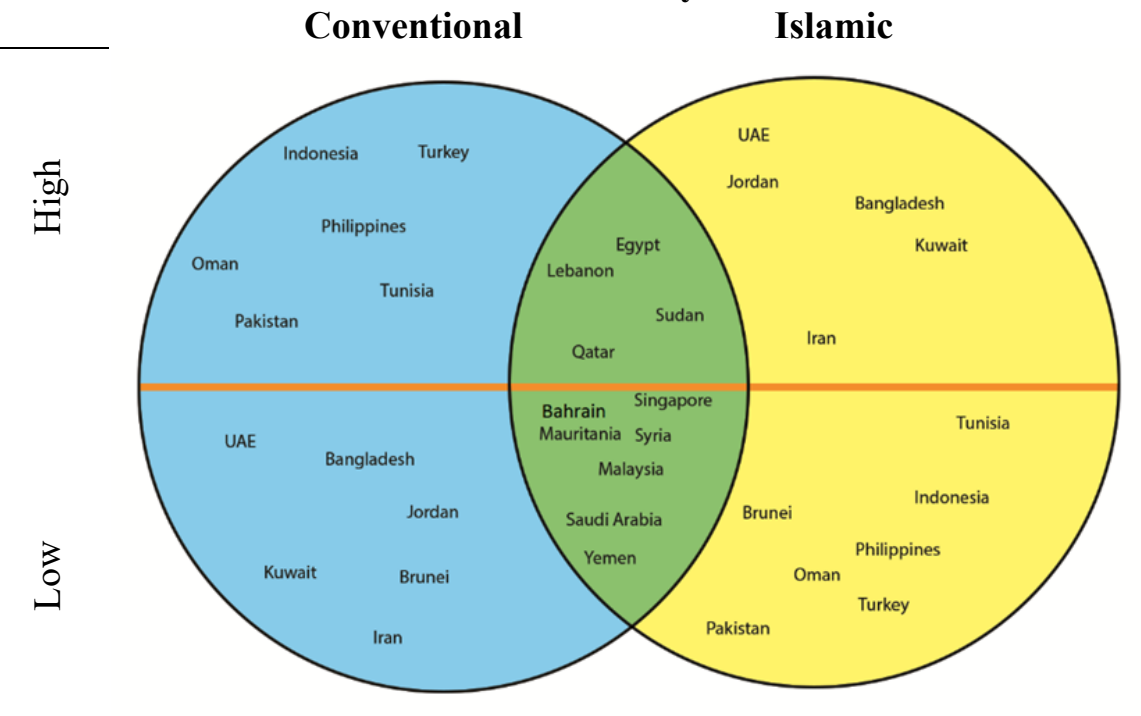

Panel B: Convergence Rate

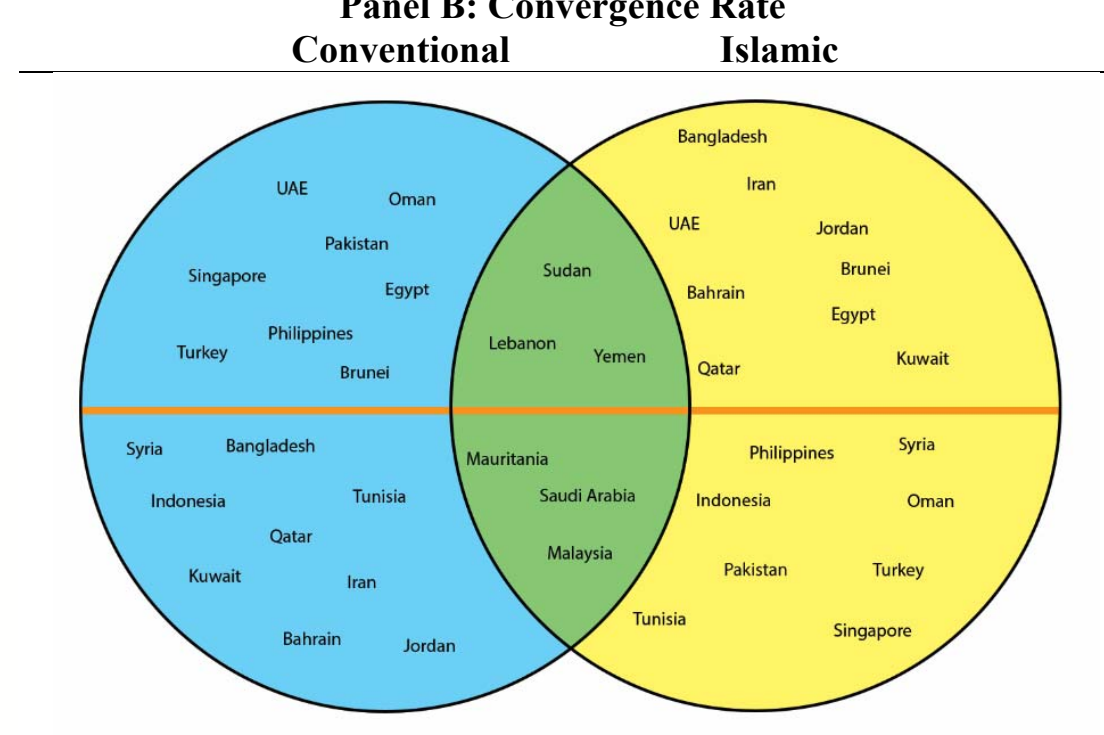

Notes: Classification based on the steady states as estimated from the random coefficients model. A transformation is applied to convert the continuous beta steady states into a binary variable denoting as 1 the High steady state banking systems (average value $=-0.0597$; average efficiency $=0.942$ ) and as 0 the Low steady state ones (average value $=$ 0.1506 ; average efficiency $=0.860)$. The threshold for this separation is the median value here $(-0.090$; average efficiency $=0.914)$. Classification is based on 2 variables, Bank Type and Country Identifier. Classification based on the beta convergence rate as estimated from the random coefficients model. A transformation is applied to convert the continuous beta convergence rates into a binary variable denoting as 1 the Low convergence banking systems (average beta $=-0.338$ ) and as 0 the High convergence ones (average beta $=-0.770)$. The threshold for this separation is the median value here $(-0.530)$. Classification is based on 2 variables, Bank Type and Country Identifier. 
Table 1: Bank observations by types and country

\begin{tabular}{lrrr}
\hline & All banks & Conventional banks & Islamic banks \\
\hline Bahrain & 213 & 118 & 95 \\
Bangladesh & 161 & 136 & 25 \\
Brunei & 18 & 16 & 2 \\
Egypt & 361 & 325 & 36 \\
Indonesia & 854 & 785 & 69 \\
Iran & 156 & 3 & 153 \\
Jordan & 187 & 151 & 36 \\
Kuwait & 145 & 65 & 80 \\
Lebanon & 409 & 394 & 15 \\
Malaysia & 195 & 127 & 68 \\
Mauritania & 93 & 76 & 17 \\
Oman & 92 & 88 & 4 \\
Pakistan & 153 & 99 & 54 \\
Philippines & 230 & 224 & 6 \\
Qatar & 119 & 84 & 35 \\
Saudi Arabia & 173 & 128 & 45 \\
Singapore & 111 & 103 & 8 \\
Sudan & 227 & 66 & 161 \\
Syria & 87 & 74 & 13 \\
Tunisia & 180 & 178 & 2 \\
Turkey & 311 & 282 & 29 \\
United Arab Emirates & 314 & 220 & 94 \\
Yemen & 75 & 33 & 42 \\
\hline
\end{tabular}


Table 2: Descriptive Statistics of ODF model variables.

\begin{tabular}{|c|c|c|c|c|c|c|c|c|c|}
\hline \multirow[b]{2}{*}{ Variable } & \multicolumn{3}{|c|}{ All banks } & \multicolumn{3}{|c|}{ Conventional banks } & \multicolumn{2}{|c|}{ Islamic banks } & \multirow[b]{2}{*}{ Median } \\
\hline & Mean & S.D. & Median & Mean & S.D. & Median & Mean & S.D. & \\
\hline Deposits and Short-Term Funding $\left(x_{1}\right)$ & 5,276 & 11,949 & 1,209 & 5,715 & 13,077 & 1,280 & 3,755 & 6,483 & 1,025 \\
\hline Fixed Assets $\left(x_{2}\right)$ & 92 & 239 & 18 & 75 & 171 & 19 & 151 & 386 & 16 \\
\hline General and Administration Expenses $\left(x_{3}\right)$ & 128 & 265 & 33 & 129 & 268 & 34 & 127 & 257 & 30 \\
\hline Equity $\left(x_{4}\right)$ & 732 & 1,641 & 170 & 784 & 1,787 & 166 & 552 & 954 & 177 \\
\hline Total Loans $\left(y_{1}\right)$ & 4,864 & 8,975 & 785 & 3,923 & 9,789 & 795 & 2,978 & 5,188 & 680 \\
\hline Other Earning Assets $\left(y_{2}\right)$ & 2,331 & 5,666 & 471 & 2,667 & 6,295 & 524 & 1,168 & 2,071 & 344 \\
\hline
\end{tabular}

Note: Source Bankscope. All data have been adjusted to 2005 prices using the appropriate GDP deflator for each country. 
Table 3: $\beta$-convergence model estimated using various estimation methods

\begin{tabular}{|c|c|c|c|c|c|c|c|c|c|}
\hline \multirow{3}{*}{$\begin{array}{l}\text { Method } \\
\text { Model }\end{array}$} & \multicolumn{3}{|c|}{ Pooled OLS robust } & \multicolumn{3}{|c|}{ Random Effects robust } & \multicolumn{3}{|c|}{ System-GMM two-step robust } \\
\hline & (I) & (II) & (III) & (IV) & $(\mathrm{V})$ & (VI) & (VII) & (VIII) & (IX) \\
\hline & $\begin{array}{l}\text { Absolute } \beta \text { - } \\
\text { convergence }\end{array}$ & $\begin{array}{l}\text { Conditional } \beta \text { - } \\
\text { convergence }\end{array}$ & $\begin{array}{l}\text { Conditional } \beta \text { - } \\
\text { convergence }\end{array}$ & $\begin{array}{l}\text { Absolute } \beta \text { - } \\
\text { convergence }\end{array}$ & $\begin{array}{l}\text { Conditional } \beta- \\
\text { convergence }\end{array}$ & $\begin{array}{l}\text { Conditional } \beta \text { - } \\
\text { convergence }\end{array}$ & $\begin{array}{l}\text { Absolute } \beta \text { - } \\
\text { convergence }\end{array}$ & $\begin{array}{l}\text { Conditional } \beta- \\
\text { convergence }\end{array}$ & $\begin{array}{l}\text { Conditional } \beta \text { - } \\
\text { convergence }\end{array}$ \\
\hline$\beta$ coefficient & $-0.283^{* * *}$ & $-0.282^{* * *}$ & $-0.332^{* * *}$ & $-0.363^{* * *}$ & $-0.378^{* * *}$ & $-0.402^{* * * *}$ & $-0.442^{* * *}$ & $-0.473^{* * *}$ & -0.489 \\
\hline & $(0.027)$ & $(0.004)$ & $(0.072)$ & $(0.030)$ & $(0.053)$ & $(0.077)$ & $(0.063)$ & $(0.081)$ & $(0.331)$ \\
\hline TYPE & & $-0.014^{*}$ & -0.016 & & -0.010 & -0.019 & & -0.006 & 0.015 \\
\hline & & $(0.010)$ & $(0.011)$ & & $(0.012)$ & $(0.009)$ & & $(0.023)$ & $(0.032)$ \\
\hline TYPE & & -0.017 & -0.018 & & 0.020 & -0.014 & & 0.059 & 0.161 \\
\hline$\times \ln \left(u_{i, t-1}\right)$ & & $(0.055)$ & $(0.059)$ & & $(0.061)$ & $(0.048)$ & & $(0.110)$ & $(0.146)$ \\
\hline Constant & $\begin{array}{l}-0.053^{* * *} \\
(0.005)\end{array}$ & $\begin{array}{l}-0.051^{* * *} \\
(0.006)\end{array}$ & $\begin{array}{l}-0.059^{* * *} \\
(0.014)\end{array}$ & $\begin{array}{l}-0.071^{* * *} \\
(0.005)\end{array}$ & $\begin{array}{l}-0.070^{* * *} \\
(0.009)\end{array}$ & $\begin{array}{l}-0.070^{* * *} \\
(0.014)\end{array}$ & $\begin{array}{l}-0.082^{* * *} \\
(0.012)\end{array}$ & $\begin{array}{l}-0.086^{* * *} \\
(0.015)\end{array}$ & $\begin{array}{l}-0.088 \\
(0.061)\end{array}$ \\
\hline $\begin{array}{l}\text { Country shift } \\
\text { dummies }\end{array}$ & No & No & Yes & No & No & Yes & No & No & Yes \\
\hline $\begin{array}{l}\text { Year shift } \\
\text { dummies }\end{array}$ & No & No & Yes & No & No & Yes & No & No & Yes \\
\hline $\begin{array}{l}\text { Country slope } \\
\text { dummies }\end{array}$ & No & No & Yes & No & No & Yes & No & No & Yes \\
\hline $\begin{array}{l}\text { Year slope } \\
\text { dummies }\end{array}$ & No & No & No & No & No & No & No & No & No \\
\hline$m_{1}$ p-value & & & & & & & 0.000 & 0.000 & 0.000 \\
\hline$m_{2}$ p-value & & & & & & & 0.533 & 0.507 & 0.465 \\
\hline Sargan/Hansen & & & & & & & 0.092 & 0.194 & 0.574 \\
\hline $\begin{array}{l}\text { p-value } \\
\mathbf{D}^{2}\end{array}$ & $0>25$ & ( 200 & 0250 & $0>05$ & 0 & 0256 & & & \\
\hline
\end{tabular}

Notes: The table reports estimated coefficients and standard errors in parentheses. OLS=ordinary least squares. TYPE takes the value 1 for Islamic banks and zero otherwise. $N=4179$ bank year observations for all models, and $T=15$ years. Tests for first- and second order autocorrelation in the system-GMM model are denoted by $\mathrm{m} 1$ and $\mathrm{m} 2$, respectively. Sargan/Hansen is a test of the over-identifying restrictions relevant to the system-GMM model. , , denote statistical significance at the 1,5 , $10 \%$ level respectively. 
Table 4: RPM conditional $\beta$-convergence

\begin{tabular}{lrrrr}
\hline \multicolumn{1}{l}{ Model (7) } & All & Islamic & Conventional & p-value \\
\hline$\beta$ & -0.554 & -0.525 & -0.564 & 0.209 \\
& $(0.000)$ & & & \\
$\alpha$ & -0.105 & -0.112 & -0.102 & 0.175 \\
& $(0.000)$ & & & \\
Number of banks & 388 & 84 & 304 & \\
Chi-sq & 315.47 & & & \\
& $(0.000)$ & & & \\
\hline
\end{tabular}

Notes: The table reports the average estimated coefficients for All banks, Islamic banks and Conventional banks, while the p-values are given in parentheses. The p-value column reports the results of the Wald tests for the equality of the convergence rates $(\beta)$ and steady states $(\alpha)$ between

Islamic and conventional banks. 
Table 5: Classification Trees Goodness of Fit Statistics

\begin{tabular}{lcccccc}
\hline Dependent Variable & \multicolumn{3}{c}{ Steady State } & \multicolumn{3}{c}{ Convergence Rate } \\
\hline Accuracy (\%) & 65.10 & 62.40 & 51.60 & 64.90 & 61.90 & 52.80 \\
AUROC & 0.703 & 0.681 & 0.514 & 0.711 & 0.654 & 0.533 \\
EMC & 0.840 & 1.375 & 0.986 & 1.050 & 1.249 & 1.875 \\
Pseudo-R ${ }^{2}$ & 0.406 & 0.362 & 0.028 & 0.422 & 0.308 & 0.066 \\
& & & & & & \\
Explanatory Variables & & & & & & Yes \\
Country & Yes & Yes & No & Yes & No \\
Islamic Bank & Yes & No & Yes & Yes & No & Yes \\
\hline
\end{tabular}

Notes: AUROC and EMC denote the Area Under the Receiver Operating Characteristic curve and

Expected Misclassification Cost respectively. 
Table 6. Beta Convergence Rate and Steady State Classifications

\begin{tabular}{|c|c|c|c|c|c|c|}
\hline & \multicolumn{3}{|c|}{ Panel A: Steady State } & \multicolumn{3}{|c|}{ Panel B: Convergence Rate } \\
\hline & Conventional & Conventional $\cap$ Islamic & Islamic & Conventional & Conventional $\cap$ Islamic & Islamic \\
\hline \multirow{9}{*}{ 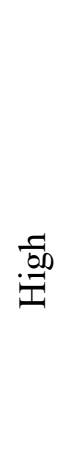 } & Indonesia & Egypt & UAE & UAE & Lebanon & UAE \\
\hline & Oman & Lebanon & Bangladesh & Brunei & Sudan & Bahrain \\
\hline & Pakistan & Qatar & Iran & Egypt & Yemen & Bangladesh \\
\hline & Philippines & Sudan & Jordan & Oman & & Brunei \\
\hline & Tunisia & & Kuwait & Pakistan & & Egypt \\
\hline & Turkey & & & Philippines & & Iran \\
\hline & & & & Singapore & & Jordan \\
\hline & & & & Turkey & & Kuwait \\
\hline & & & & & & Qatar \\
\hline \multirow{9}{*}{ 占 } & Bahrain & Malaysia & Bahrain & Bahrain & Malaysia & Indonesia \\
\hline & Bangladesh & Mauritania & Brunei & Bangladesh & Mauritania & Oman \\
\hline & Brunei & Saudi Arabia & Indonesia & Indonesia & Saudi Arabia & Pakistan \\
\hline & $\operatorname{Iran}^{*}$ & Singapore & Oman & $\operatorname{Iran}^{*}$ & & Philippines \\
\hline & Jordan & Syria & Pakistan & Jordan & & Singapore \\
\hline & Kuwait & Yemen & Philippines & Kuwait & & Syria \\
\hline & UAE & & Tunisia & Qatar & & Tunisia \\
\hline & & & Turkey & Syria & & Turkey \\
\hline & & & & Tunisia & & \\
\hline
\end{tabular}

Notes: Notes: Classification based on the steady state as estimated from the random coefficients model. A transformation is applied to convert the continuous beta steady states into a binary variable denoting as 1 the High steady state banking systems (average value $=-0.0597$; average efficiency $=0.942$ ) and as 0 the Low steady state ones (average value $=-$ Type and Country Identifier. Classification based on the separation is the median value here $(-0.090$; average efficiency $=0.914)$. Classification is based on 2 variables, Bank continuous beta convergence rates into a binary variable denoting as 1 the Low convergence banking systems (average beta $=-0.338$ ) and as 0 the High convergence ones (average beta $=-0.770)$. The threshold for this separation is the median value here $(-0.530)$. Classification is based on 2 variables, Bank Type and Country Identifier. * Iran is typically considered an Islamic-banking country; however conventional banks are allowed to operate within specific free economic zones (Rooz Online, 2010; Presstv.com, 2010). 
Table 7. Characteristics of banking systems.

\begin{tabular}{|c|c|c|c|}
\hline & Not-Fully Aligned & Fully Aligned & t-statistic \\
\hline \multicolumn{4}{|c|}{ Financial Structure: Access } \\
\hline Account at a formal financial institution $(\%$ age $15+)$ & 43.912 & 44.176 & 0.098 \\
\hline Account used for business purposes $(\%$ age $15+)$ & 7.178 & 6.621 & 0.873 \\
\hline Account used to receive government payments $(\%$ age $15+)$ & 14.325 & 5.129 & $6.472^{* * *}$ \\
\hline Account used to receive remittances $(\%$ age $15+)$ & 7.637 & 5.964 & $2.800^{* * *}$ \\
\hline Account used to receive wages $(\%$ age $15+)$ & 15.241 & 16.058 & 0.571 \\
\hline Saved any money in the past year $(\%$ age $15+)$ & 42.712 & 44.595 & 1.135 \\
\hline Saved at a financial institution in the past year $(\%$ age $15+)$ & 17.116 & 18.967 & 1.530 \\
\hline Loan in the past year $(\%$ age $15+)$ & 45.411 & 39.644 & $4.061^{* * *}$ \\
\hline Loan from a financial institution in the past year $(\%$ age & 12.407 & 10.373 & $3.315^{* * *}$ \\
\hline Loan from a private lender in the past year $(\%$ age $15+)$ & 5.177 & 5.178 & 0.002 \\
\hline Loan from an employer in the past year $(\%$ age $15+)$ & 4.782 & 5.990 & $2.842^{* * *}$ \\
\hline Loan through store credit in the past year $(\%$ age $15+)$ & 13.645 & 15.370 & $1.694^{*}$ \\
\hline Loan from family or friends in the past year $(\%$ age $15+)$ & 31.180 & 28.705 & $2.157^{* *}$ \\
\hline \multicolumn{4}{|c|}{ Financial Structure: Depth } \\
\hline Domestic credit provided by financial sector (\% of GDP) & 57.157 & 98.085 & $9.933^{* * *}$ \\
\hline Domestic credit to private sector by banks (\% of GDP) & 40.807 & 64.958 & $8.045^{* * *}$ \\
\hline Syndicated loan average maturity (years) & 6.998 & 7.388 & $1.876^{*}$ \\
\hline Credit to government and state-owned enterprises / GDP & 17.175 & 25.666 & $4.817^{* * *}$ \\
\hline Liquid liabilities / GDP (\%) & 57.192 & 109.386 & $10.929^{* * *}$ \\
\hline Bank deposits / GDP (\%) & 50.706 & 99.753 & $10.346^{* * *}$ \\
\hline Life Insurance Premium Volume / GDP (\%) & 0.614 & 1.150 & $4.759^{* * *}$ \\
\hline Non-Life Insurance Premium Volume / GDP (\%) & 0.718 & 0.913 & $4.532^{* * *}$ \\
\hline Loans from non-Resident Banks / GDP (\%) & 9.632 & 28.178 & $10.148^{* * *}$ \\
\hline Offshore Bank Deposits / Domestic Bank Deposits (\%) & 15.240 & 21.767 & $3.913^{* * *}$ \\
\hline \multicolumn{4}{|c|}{ Macroeconomic } \\
\hline Trade $(\%$ of GDP) & 86.307 & 105.008 & $2.740^{* * * *}$ \\
\hline Inflation $(\%)$ & 8.993 & 6.614 & $4.508^{* * *}$ \\
\hline Oil rents $(\%$ of GDP) & 8.546 & 9.602 & 0.819 \\
\hline GDP growth $(\%)$ & 4.907 & 4.630 & $2.161^{* *}$ \\
\hline \multicolumn{4}{|c|}{ Market structure } \\
\hline Business extent of disclosure index & 6.603 & 7.095 & 1.539 \\
\hline Strength of legal rights index & 2.543 & 3.650 & $5.394^{* * *}$ \\
\hline Hirschman-Herfindahl index & 0.191 & 0.308 & $8.678^{* * *}$ \\
\hline Hirschman-Herfindahl (Conventional sector) & 0.213 & 0.387 & $10.586^{* * *}$ \\
\hline Hirschman-Herfindahl (Islamic sector) & 0.398 & 0.436 & $1.829^{*}$ \\
\hline \multicolumn{4}{|c|}{ Bank-specific } \\
\hline Total Assets (ln) & 9.092 & 9.131 & 0.154 \\
\hline Equity / Total Assets & 14.771 & 14.322 & 0.344 \\
\hline Net Interest Revenue / Total Assets & 3.694 & 2.734 & $3.197^{* * *}$ \\
\hline Other Operating Income / Total Assets & 2.027 & 2.167 & 0.637 \\
\hline Net Interest Margin & 4.550 & 3.869 & 0.733 \\
\hline ROA & 1.341 & 1.261 & 0.306 \\
\hline ROE & 10.101 & 11.161 & 0.681 \\
\hline Cost / Income & 60.278 & 60.156 & 0.038 \\
\hline Net Loans / Total Assets & 51.499 & 39.805 & $6.152^{* * *}$ \\
\hline Liquid Assets / Customer Deposits and Short-Term Funding & 41.597 & 47.396 & 1.460 \\
\hline$z$ - score & 24.214 & 41.839 & $4.487^{* * *}$ \\
\hline Income diversity & 0.357 & 0.553 & $2.583^{* * *}$ \\
\hline
\end{tabular}

Notes: Fully Aligned (FA) refers to the banking systems that lie inside the intersections of both graphs of figure 5 (steady state and convergence), while Not-Fully Aligned (NFA) refers to those that lie outside. ${ }^{* * *},{ }^{* *},{ }^{*}$ denote statistical significance at the 1,5 and $10 \%$ level respectively. Sources: Global Financial Development Database, authors' calculations. 
Table 8. Panel logit estimation results.

\begin{tabular}{|c|c|c|c|c|}
\hline Models & I & II & III & IV \\
\hline \multirow[t]{2}{*}{ Business extent of disclosure index } & $0.193^{* * *}$ & $0.247^{* * *}$ & $0.412^{* * *}$ & $0.570^{* * *}$ \\
\hline & $(0.052)$ & $(0.067)$ & $(0.119)$ & $(0.133)$ \\
\hline \multirow[t]{2}{*}{ Domestic credit to private sector ( $\%$ of GDP) } & $0.051^{* * *}$ & $0.062^{* * *}$ & $0.122^{* * *}$ & $0.143^{* * *}$ \\
\hline & $(0.006)$ & $(0.009)$ & $(0.039)$ & $(0.031)$ \\
\hline \multirow[t]{2}{*}{ Inflation, GDP deflator (annual \%) } & $-0.128^{* * *}$ & $-0.103^{* *}$ & $-0.141^{* * * *}$ & $-0.135^{*}$ \\
\hline & $(0.032)$ & $(0.042)$ & $(0.055)$ & $(0.071)$ \\
\hline \multirow[t]{2}{*}{ Strength of legal rights index } & 0.229 & -0.002 & $-0.758^{* *}$ & $-1.068^{* * *}$ \\
\hline & $(0.270)$ & $(0.256)$ & $(0.385)$ & $(0.314)$ \\
\hline \multirow[t]{2}{*}{ Bank credit to bank deposits (\%) } & $0.029^{* * *}$ & $0.055^{* * *}$ & $0.0590^{* *}$ & $0.099^{* * *}$ \\
\hline & $(0.008)$ & $(0.008)$ & $(0.020)$ & $(0.018)$ \\
\hline \multirow[t]{2}{*}{ Loan through store credit in the past year } & $0.282^{* * *}$ & $0.290^{* * *}$ & $0.528^{* * *}$ & $0.622^{* * *}$ \\
\hline & $(0.043)$ & $(0.034)$ & $(0.171)$ & $(0.124)$ \\
\hline \multirow[t]{2}{*}{ Income Diversity } & $1.102^{* *}$ & $2.227^{* * *}$ & 0.859 & $2.561^{*}$ \\
\hline & $(0.450)$ & $(0.635)$ & $(0.725)$ & $(1.335)$ \\
\hline \multirow[t]{2}{*}{ Total Assets (ln) } & & $-0.547^{* * *}$ & & $-0.838^{* * *}$ \\
\hline & & $(0.177)$ & & $(0.196)$ \\
\hline \multirow[t]{2}{*}{ Equity / Total Assets } & & $-0.071^{* * *}$ & & $-0.143^{* * *}$ \\
\hline & & $(0.024)$ & & $(0.039)$ \\
\hline \multirow[t]{2}{*}{ Net Interest Margin } & & -0.006 & & 0.052 \\
\hline & & $(0.012)$ & & $(0.067)$ \\
\hline \multirow[t]{2}{*}{ Return on Equity } & & $0.026^{* * *}$ & & 0.028 \\
\hline & & $(0.010)$ & & $(0.023)$ \\
\hline \multirow{2}{*}{ Cost / Income } & & -0.007 & & -0.006 \\
\hline & & $(0.007)$ & & $0.010)$ \\
\hline \multirow[t]{2}{*}{ Net Loans / Total Assets } & & $-0.048^{* * *}$ & & $-0.058^{* * *}$ \\
\hline & & $(0.015)$ & & $(0.022)$ \\
\hline \multirow[t]{2}{*}{ z - score } & & $0.013^{* * *}$ & & $0.026^{* * *}$ \\
\hline & & $(0.004)$ & & $(0.008)$ \\
\hline \multirow[t]{2}{*}{ Hirschman-Herfindahl Index (CB) } & $5.977^{* * *}$ & $6.059^{* * *}$ & $9.143^{* * *}$ & $9.150^{* * *}$ \\
\hline & $(0.628)$ & $(0.876)$ & $(2.378)$ & $(1.255)$ \\
\hline \multirow{2}{*}{ Hirschman-Herfindahl Index (IB) } & $11.91^{* * *}$ & $10.07^{* * *}$ & $15.48^{* * *}$ & $14.40^{* * *}$ \\
\hline & $(3.188)$ & $(2.496)$ & $(4.468)$ & $(2.682)$ \\
\hline \multirow[t]{2}{*}{ Business extent of disclosure index $x$ IB } & & & $-1.129^{* * *}$ & $-1.254^{* * *}$ \\
\hline & & & $(0.293)$ & $(0.304)$ \\
\hline Domestic credit to private sector (\% of GDP) x IB & & & 0.0159 & -0.0356 \\
\hline & & & $(0.019)$ & $(0.030)$ \\
\hline Inflation, GDP deflator (annual \%) x IB & & & $-1.393^{* * *}$ & $-1.212^{* * *}$ \\
\hline & & & $(0.513)$ & $(0.398)$ \\
\hline Strength of legal rights index $\mathrm{x}$ IB & & & $0.588^{*}$ & $1.408^{* * *}$ \\
\hline & & & $(0.342)$ & $(0.376)$ \\
\hline Bank credit to bank deposits (\%) x IB & & & $0.0714^{* * *}$ & $0.048^{*}$ \\
\hline & & & $(0.021)$ & $(0.028)$ \\
\hline Loan through store credit in the past year $\mathrm{x}$ IB & & & $0.558^{* * *}$ & 0.292 \\
\hline & & & $(0.197)$ & $(0.192)$ \\
\hline Income Diversity x IB & & & 1.812 & 1.988 \\
\hline & & & $(1.208)$ & $(1.764)$ \\
\hline Total Assets $(\ln ) \times$ IB & & & & $0.783^{* * *}$ \\
\hline & & & & $(0.297)$ \\
\hline Equity / Total Assets & & & & 0.074 \\
\hline & & & & $(0.077)$ \\
\hline Net Interest Margin x IB & & & & -0.039 \\
\hline & & & & $(0.068)$ \\
\hline Return on Equity $\mathrm{x}$ IB & & & & 0.046 \\
\hline & & & & $(0.052)$ \\
\hline Cost / Income x IB & & & & 0.024 \\
\hline & & & & $(0.016)$ \\
\hline Net Loans / Total Assets x IB & & & & -0.037 \\
\hline & & & & $(0.035)$ \\
\hline z-score x IB & & & & -0.008 \\
\hline
\end{tabular}




\begin{tabular}{lcccc} 
& & & $(0.015)$ \\
Constant & $-18.45^{* * *}$ & $-13.88^{* * *}$ & $-30.06^{* * *}$ & $-26.51^{* * *}$ \\
& $(3.314)$ & $(2.677)$ & $(8.403)$ & $(5.338)$ \\
\hline F-statistic & 421.22 & 184.51 & 63.34 & 158.99 \\
Pseudo R & 0.463 & 0.558 & 0.560 & 0.680 \\
Observations & 435 & 435 & 435 & 435 \\
\hline
\end{tabular}

Notes: The table reports estimated coefficients and robust standard errors in brackets for the panel robust logit estimation of section 5.4 (Eq. 3). ${ }^{* * *},{ }^{* *},{ }^{*}$ denote statistical significance at the $1,5,10 \%$ level respectively. 


\section{References}

Abdul-Majid, M., Saal, D.S., Battisti, G., 2011a. Efficiency and total factor productivity change of Malaysian commercial banks. Serv. Ind. J. 31, 2117-2143. doi:10.1080/02642069.2010.503882

Abdul-Majid, M., Saal, D.S., Battisti, G., 2011b. The impact of Islamic banking on the cost efficiency and productivity change of Malaysian commercial banks. Appl. Econ. 43, 2033-2054. doi:10.1080/00036840902984381

Abdul-Majid, M., Saal, D.S., Battisti, G., 2010. Efficiency in Islamic and conventional banking: an international comparison. J. Product. Anal. 34, 25-43. doi:10.1007/s11123-009-0165-3

Abedifar, P., Ebrahim, S.M., Molyneux, P., Tarazi, A., 2015. Islamic Banking and Finance: Recent Empirical Literature and Directions for Future Research. J. Econ. Surv. 29, 637-670. doi:10.1111/joes. 12113

Abedifar, P., Hasan, I., Tarazi, A., 2016. Finance-growth nexus and dual-banking systems: Relative importance of Islamic banks. J. Econ. Behav. Organ. 132, 198-215. doi:https://doi.org/10.1016/j.jebo.2016.03.005

Abedifar, P., Molyneux, P., Tarazi, A., 2013. Risk in islamic banking. Rev. Financ. 17, 2035-2096. doi:10.1093/rof/rfs041

Aigner, D., Lovell, C.A.K., Schmidt, P., 1977. Formulation and estimation of stochastic frontier production function models. J. Econom. 6, 21-37. doi:https://doi.org/10.1016/03044076(77)90052-5

Akhtar, S., Akhtar, F., Jahromi, M., John, K., 2017. Intensity of volatility linkages in Islamic and conventional markets, in: KFUPM Islamic Banking and Finance Research Conference 2017.

Al-Hassan, A., Khamis, M., Oulidi, N., 2010. The GCC Banking Sector: Topography and Analysis. IMF Work. Pap.

Al-Jarrah, I., Molyneux, P., 2006. Cost efficiency, scale elasticity and scale economies in arab banking. Banks Bank Syst. 1, 60-89.

Al-Jarrah, I., Molyneux, P., 2005. Efficiency in Arabian Banking, in: Islamic Perspectives on Wealth Creation. Edinburgh University Press, pp. 97-117.

Al-Muharrami, S., 2008. An examination of technical, pure technical and scale efficiencies in GCC banking. Am. J. Financ. Account. 1, 152-166.

Alexakis, C., Pappas, V., Tsikouras, A., 2017. Hidden cointegration reveals hidden values in Islamic investments. J. Int. Financ. Mark. Institutions Money 46, 70-83. doi:https://doi.org/10.1016/j.intfin.2016.08.006

Alhomaidi, A., Kabir Hassan, M., 2017. The effect of implicit market barriers on stock trading and liquidity, in: KFUPM Islamic Banking and Finance Research Conference 2017.

Altunbaş, Y., Gardener, E.P.M., Molyneux, P., Moore, B., 2001. Efficiency in European banking. Eur. Econ. Rev. 45, 1931-1955.

Alzahrani, M., Megginson, W.L., 2017. Finance as worship: A survey of Islamic finance research. SSRN eLibrary.

Andrieş, A.M., Căpraru, B., 2014. Convergence of Bank Efficiency in Emerging Markets: The Experience of Central and Eastern European Countries. Emerg. Mark. Financ. Trade 50, 9-30. doi:10.2753/REE1540-496X5004S401

Anginer, D., Demirgüç-Kunt, A., Zhu, M., 2014. How does competition affect bank systemic risk? J. Financ. Intermediation 23, 1-26. doi:10.1016/j.jfi.2013.11.001

Arellano, M., Bover, O., 1995. Another look at the instrumental variable estimation of errorcomponents models. J. Econom. 68, 29-51. doi:https://doi.org/10.1016/0304-4076(94)01642-D

Ariss, R.T., 2010. Competitive conditions in Islamic and conventional banking: A global perspective. Rev. Financ. Econ. 19, 101-108. doi:https://doi.org/10.1016/j.rfe.2010.03.002

Awdeh, A., El Moussawi, C., 2009. Bank efficiency and foreign ownership in the Lebanese banking sector. Rev. Middle East Econ. Financ. 5, 66-87.

Bader, M.K.I., Mohamad, S., Ariff, M., Hassan, T., 2008. Cost, revenue, and profit efficiencyof Islamic versus conventional banks: International evidence using data envelopment analysis. Islam. Econ. Stud. 15, 24-76.

Baele, L., Farooq, M., Ongena, S., 2014. Of religion and redemption: Evidence from default on Islamic loans. J. Bank. Financ. 44, 141-159. doi:10.1016/j.jbankfin.2014.03.005 
Barajas, A., Steiner, R., Salazar, N., 1999. Interest Spreads in Banking in Colombia, 1974-96. IMF Staff Pap. 46, 196-224. doi:10.2307/3867667

Barros, C.P., Williams, J., 2013. The random parameters stochastic frontier cost function and the effectiveness of public policy: Evidence from bank restructuring in Mexico. Int. Rev. Financ. Anal. 30, 98-108. doi:https://doi.org/10.1016/j.irfa.2013.06.006

Beck, T., De Jonghe, O., Schepens, G., 2013a. Bank competition and stability: Cross-country heterogeneity. J. Financ. Intermediation2 22, 218-244.

Beck, T., Demirgüç-Kunt, A., Merrouche, O., 2013b. Islamic vs. conventional banking: Business model, efficiency and stability. J. Bank. Financ. 37, 433-447. doi:https://doi.org/10.1016/j.jbankfin.2012.09.016

Berger, A.N., Boubakri, N., Guedhami, O., Li, X., 2017. Liquidity creation and financial stability implications of Islamic banking: Evidence from a multinational study, in: KFUPM Islamic Banking and Finance Research Conference 2017.

Berger, A.N., DeYoung, R., 1997. Problem Loans and Cost Efficiency in Commercial Banks. J. Bank. Financ. 21, 849-870.

Berger, A.N., Hasan, I., Klapper, L.F., 2004. Further Evidence on the Link between Finance and Growth: An International Analysis of Community Banking and Economic Performance. J. Financ. Serv. Res. 25, 169-202. doi:10.1023/B:FINA.0000020659.33510.b7

Berger, A.N., Humphrey, D.B., 1997. Efficiency of financial institutions: International survey and directions for future research. Eur. J. Oper. Res. 98, 175-212. doi:https://doi.org/10.1016/S03772217(96)00342-6

Berger, A.N., Mester, L.J., 1997. Inside the black box: What explains differences in the efficiencies of financial institutions? J. Bank. Financ. 21, 895-947. doi:https://doi.org/10.1016/S03784266(97)00010-1

Berger, A.N., Sedunov, J., 2017. Bank liquidity creation and real economic output. J. Bank. Financ. 81, 1-19. doi:https://doi.org/10.1016/j.jbankfin.2017.04.005

Bertay, A.C., Demirgüç-Kunt, A., Huizinga, H., 2013. Do we need big banks? Evidence on performance, strategy and market discipline. J. Financ. Intermediation 22, 532-558. doi:10.1016/j.jfi.2013.02.002

Berzal, F., Cubero, J.-C., Cuenca, F., Martín-Bautista, M.J., 2003. On the quest for easy-to-understand splitting rules. Data Knowl. Eng. 44, 31-48. doi:10.1016/S0169-023X(02)00062-9

Blundell, R., Bond, S., 1998. Initial conditions and moment restrictions in dynamic panel data models. J. Econom. 87, 115-143. doi:https://doi.org/10.1016/S0304-4076(98)00009-8

Breiman, L., Friedman, J., Stone, C.J., Olshen, R.A., 1984. Classification and regression trees. CRC press.

Brown, K., Skully, M.T., 2002. International studies in comparative banking: a survey of recent developments. SSRN eLibrary.

Casu, B., Girardone, C., 2010. Integration and efficiency convergence in EU banking markets. Omega 38, 260-267. doi:10.1016/j.omega.2009.08.004

Casu, B., Girardone, C., 2004. Large banks' efficiency in the single European market. Serv. Ind. J. 24, 129-142.

Casu, B., Girardone, C., Molyneux, P., 2004. Productivity change in European banking: A comparison of parametric and non-parametric approaches. J. Bank. Financ. 28, 2521-2540.

Charnes, A., Cooper, W.W., Rhodes, E., 1978. Measuring the efficiency of decision making units. Eur. J. Oper. Res. 2, 429-444. doi:https://doi.org/10.1016/0377-2217(78)90138-8

Chen, C., Delmas, M.A., Lieberman, M.B., 2015. Production frontier methodologies and efficiency as a performance measure in strategic management research. Strateg. Manag. J. 36, 19-36.

Choudhury, M.A., Hoque, M.Z., 2006. Corporate governance in Islamic perspective. Corp. Gov. 6, 116-128. doi:0.1108/14720700610655132

Čihák, M., Hesse, H., 2010. Islamic Banks and Financial Stability: An Empirical Analysis. J. Financ. Serv. Res. 38, 95-113. doi:10.1007/s10693-010-0089-0

Coelli, T., Perelman, S., 2000. Technical efficiency of European railways: a distance function approach. Appl. Econ. 32, 1967-1976.

Delen, D., Kuzey, C., Uyar, A., 2013. Measuring firm performance using financial ratios: A decision tree approach. Expert Syst. Appl. 40, 3970-3983. doi:10.1016/j.eswa.2013.01.012 
Delis, M.D., Molyneux, P., Pasiouras, F., 2011. Regulations and productivity growth in banking: Evidence from transition economies. J. Money, Credit Bank. 43, 735-764.

Demsetz, H., 1973. Industry structure, market rivalry, and public policy. J. Law Econ. 16, 1-9.

Di, L., Shaiban, M.S., Shavkatovich Hasanov, A., 2017. Contagion effect from US banking to conventional and Islamic banking in dual-banking system during financial crisis, in: KFUPM Islamic Banking and Finance Research Conference 2017.

Dietsch, M., Lozano-Vivas, A., 2000. How the environment determines banking efficiency: A comparison between French and Spanish industries. J. Bank. Financ. 24, 985-1004. doi:https://doi.org/10.1016/S0378-4266(99)00115-6

Dong, Y., Girardone, C., Kuo, J.-M., 2017. Governance, efficiency and risk taking in Chinese banking. Br. Account. Rev. 49, 211-229. doi:https://doi.org/10.1016/j.bar.2016.08.001

Durlauf, S.N., Johnson, P.A., 1995. Multiple regimes and cross-country growth behaviour. J. Appl. Econom. 10, 365-384.

El-Gamal, M.A., 2006. Islamic Finance: Law, Economics, and Practice. Cambridge University Press.

El-Hawary, D., Grais, W., 2003. Regulating Islamic financial institutions: The nature of the regulated. World Bank Publications.

El-Gamal, M.A., Inanoglu, H., 2005. Inefficiency and heterogeneity in Turkish banking: 1990-2000. J. Appl. Econom. 20, 641-664.

Elnahass, M., Izzeldin, M., Abdelsalam, O., 2014. Loan loss provisions, bank valuations and discretion: A comparative study between conventional and Islamic banks. J. Econ. Behav. Organ. 103, S160 S173. doi:10.1016/j.jebo.2013.08.018

Emrouznejad, A., Anouze, A.L., 2010. Data envelopment analysis with classification and regression tree - A case of banking efficiency. Expert Syst. 27, 231-246. doi:10.1111/j.14680394.2010.00516.x

Ernst \& Young, 2016. World Islamic Banking Competitiveness Report: New realities, new opportunities.

Farag, H., Mallin, C., Ow-Yong, K., 2017. Corporate governance in Islamic banks: New insights for dual board structure and agency relationships. J. Int. Financ. Mark. Institutions Money. doi:https://doi.org/10.1016/j.intfin.2017.08.002

Fethi, M.D., Pasiouras, F., 2010. Assessing bank efficiency and performance with operational research and artificial intelligence techniques: A survey. Eur. J. Oper. Res. 204, 189-198.

Fiordelisi, F., Marques-ibanez, D., Molyneux, P., 2011. Efficiency and risk in European banking q. J. Bank. Financ. 35, 1315-1326. doi:10.1016/j.jbankfin.2010.10.005

Fung, M.K., 2006. Scale economies, X-efficiency, and convergence of productivity among bank holding companies. J. Bank. Financ. 30, 2857-2874. doi:10.1016/j.jbankfin.2005.11.004

Gallizo, J.L., Moreno, J., Salvador, M., 2016. Banking Efficiency in the Enlarged European Union: Financial Crisis and Convergence. Int. Financ. 19, 66-88. doi:10.1111/infi.12083

Gelbard, E., Hussain, M., Maino, R., Mu, Y., Yehoue, E.B., 2014. Islamic finance in sub-saharan Africa: Status and prospects. International Monetary Fund.

Gheeraert, L., 2014. Does Islamic finance spur banking sector development? J. Econ. Behav. Organ. 103, S4-S20. doi:https://doi.org/10.1016/j.jebo.2014.02.013

Ghroubi, M., Abaoub, E., 2016. A meta-frontier function for the estimation of Islamic and Conventional Banks' cost and revenue efficiency: The case of Malaysia from 2006 to 2012. Int. J. Bus. Manag. 11,254

Goetz, M.R., 2018. Competition and bank stability. J. Financ. Intermediation 35, 57-69. doi:10.1016/j.jfi.2017.06.001

Gonzalez, F., 2009. Determinants of Bank-Market Structure: Efficiency and Political Economy Variables. J. Money, Credit Bank. 41, 735-754.

Grigorian, D.A., Manole, V., 2006. Determinants of commercial bank performance in transition: an application of data envelopment analysis. Comp. Econ. Stud. 48, 497-522.

Hasan, I., Koetter, M., Lensink, R., Meesters, A., 2009. Bank efficiency, financial depth, and economic growth.

Hasan, M., Dridi, J., 2011. The effects of the global crisis on Islamic and conventional banks: A comparative study. J. Int. Commer. Econ. Policy 2, 163-200.

Hassan, T., Mohamad, S., Khaled I. Bader, M., 2009. Efficiency of conventional versus Islamic banks: 
evidence from the Middle East. Int. J. Islam. middle East. Financ. Manag. 2, 46-65.

Hussan, S.M., Masih, M., 2014. Are The Profit Rates of the Islamic Investment Deposit Accounts Truly Performance Based? A Case Study of Malaysia. MPRA.

Irimia-Dieguez, A.I., Blanco-Oliver, A., Vazquez-Cueto, M.J., 2015. A Comparison of Classification/Regression Trees and Logistic Regression in Failure Models. Procedia Econ. Financ. 23, 9-14. doi:10.1016/S2212-5671(15)00493-1

Jackson, P.M., Fethi, M.D., 2000. Evaluating the efficiency of Turkish commercial banks: An application of DEA and Tobit Analysis.

Johnes, J., Izzeldin, M., Pappas, V., 2014. A comparison of performance of Islamic and conventional banks 2004-2009. J. Econ. Behav. Organ. 103, S93-S107. doi:https://doi.org/10.1016/j.jebo.2013.07.016

Kabir Hassan, M., Aliyu, S., 2017. A Contemporary Survey of Islamic Banking Literature. J. Financ. Stab. doi:https://doi.org/10.1016/j.jfs.2017.11.006

Kamarudin, F., Nordin, B.A.A., Muhammad, J., Hamid, M.A.A., 2014. Cost, Revenue and Profit Efficiency of Islamic and Conventional Banking Sector: Empirical Evidence from Gulf Cooperative Council Countries. Glob. Bus. Rev. 15, 1-24. doi:10.1177/0972150913515579

Kasman, A., Kasman, S., 2013. Efficiency Convergence in All EU Member and Candidate Countries' Banking Markets: A Dynamic Panel Data Analysis. East. Europ. Econ. 51, 50-70.

Khan, F., 2010. How 'Islamic' is Islamic Banking? J. Econ. Behav. Organ. 76, 805-820. doi:https://doi.org/10.1016/j.jebo.2010.09.015

Kose, M.A., Otrok, C., Prasad, E., 2012. Global Business Cycles: Convergence or Decoupling? Int. Econ. Rev. (Philadelphia). 53.

Koutsomanoli-Filippaki, A., Margaritis, D., Staikouras, C., 2009. Efficiency and productivity growth in the banking industry of Central and Eastern Europe. J. Bank. Financ. 33, 557-567. doi:https://doi.org/10.1016/j.jbankfin.2008.09.009

Kwan, S., Eisenbeis, R.A., 1997. Bank Risk, Capitalization, and Operating Efficiency. J. Financ. Serv. Res. 12, 117-131. doi:10.1023/A:1007970618648

Lippman, S.A., Rumelt, R.P., 1982. Uncertain imitability: An analysis of interfirm differences in efficiency under competition. Bell J. Econ. 13, 418-438.

Mamatzakis, E., Staikouras, C., Koutsomanoli-Filippaki, A., 2008. Bank efficiency in the new European Union member states: Is there convergence? Int. Rev. Financ. Anal. 17, 1156-1172. doi:10.1016/j.irfa.2007.11.001

Martynova, M., Renneboog, L., 2011. Evidence on the international evolution and convergence of corporate governance regulations. J. Corp. Financ. 17, 1531-1557. doi:https://doi.org/10.1016/j.jcorpfin.2011.08.006

McGahan, A.M., Porter, M.E., 1999. The persistence of shocks to profitability. Rev. Econ. Stat. 81, $143-153$.

Mejia, A.L., Aljabrin, S., Awad, R., Norat, M., Song, I., 2014. Regulation and supervision of Islamic banks. International Monetary Fund.

Miller, S.M., Noulas, A.G., 1997. Portfolio mix and large-bank profitability in the USA. Appl. Econ. 29, 505-512.

Mobarek, A., Kalonov, A., 2014. Comparative performance analysis between conventional and Islamic banks: empirical evidence from OIC countries. Appl. Econ. 46, 253-270.

Mohamad, S., Hassan, T., Bader, M.K.I., 2008. Efficiency of conventional versus Islamic Banks: international evidence using the Stochastic Frontier Approach (SFA). J. Islam. Econ. Bank. Financ. 4, 107-130.

Mollah, S., Hassan, M.K., Al Farooque, O., Mobarek, A., 2017a. The governance, risk-taking, and performance of Islamic banks. J. Financ. Serv. Res. 51, 195-219.

Mollah, S., Skully, M., Liljeblom, E., 2017b. Strong boards and risk-taking in Islamic banks, in: KFUPM Islamic Banking and Finance Research Conference 2017.

Mollah, S., Zaman, M., 2015. Shari' ah supervision, corporate governance and performance: Conventional vs. Islamic banks. J. Bank. Financ. 58, 418-435. doi:https://doi.org/10.1016/j.jbankfin.2015.04.030

Olson, D., Zoubi, T., 2017. Convergence in bank performance for commercial and Islamic banks during and after the Global Financial Crisis. Q. Rev. Econ. Financ. 65, 71-87. 
doi:https://doi.org/10.1016/j.qref.2016.06.013

Olson, D., Zoubi, T.A., 2008. Using accounting ratios to distinguish between Islamic and conventional banks in the GCC region. Int. J. Account. 43, 45-65. doi:https://doi.org/10.1016/j.intacc.2008.01.003

Pappas, V., Ongena, S., Izzeldin, M., Fuertes, A.-M., 2017. A survival analysis of Islamic and conventional banks. J. Financ. Serv. Res. 51, 221-256.

Pasiouras, F., 2008. Estimating the technical and scale efficiency of Greek commercial banks: The impact of credit risk, off-balance sheet activities, and international operations. Res. Int. Bus. Financ. 22, 301-318. doi:https://doi.org/10.1016/j.ribaf.2007.09.002

Phillips, P.C.B., Sul, D., 2009. Economic transition and growth. J. Appl. Econom. 24, 1153-1185.

Phillips, P.C.B., Sul, D., 2007. Transition modeling and econometric convergence tests. Econometrica $75,1771-1855$.

Roodman, D., 2006. How to do xtabond2: An introduction to difference and system GMM in Stata. Stata J. 9, 86-136.

Rughoo, A., Sarantis, N., 2014. The global financial crisis and integration in European retail banking. J. Bank. Financ. 40, 28-41. doi:10.1016/j.jbankfin.2013.11.017

Rughoo, A., Sarantis, N., 2012. Integration in European retail banking: Evidence from savings and lending rates to non-financial corporations. J. Int. Financ. Mark. Institutions Money 22, 1307 1327. doi:https://doi.org/10.1016/j.intfin.2012.08.001

Saeed, M., Izzeldin, M., 2016. Examining the relationship between default risk and efficiency in Islamic and conventional banks. J. Econ. Behav. Organ. 132, 127-154. doi:10.1016/j.jebo.2014.02.014

Sala-i-Martin, X.X., 1996. The classical approach to convergence analysis. Econ. J. 106, 1019-1036.

Schaeck, K., Cihák, M., 2014. Competition, Efficiency, and Stability in Banking. Financ. Manag. 43, 215-241. doi:10.1111/fima.12010

Song, I., Oosthuizen, C., 2014. Islamic banking regulation and supervision: Survey results and challenges. International Monetary Fund.

Sorwar, G., Pappas, V., Pereira, J., Nurullah, M., 2016. To debt or not to debt: Are Islamic banks less risky than conventional banks? J. Econ. Behav. Organ. 132, 113-126. doi:https://doi.org/10.1016/j.jebo.2016.10.012

Srairi, S.A., 2010. Cost and profit efficiency of conventional and Islamic banks in GCC countries. J. Product. Anal. 34, 45-62.

Staikouras, C., Mamatzakis, E., Koutsomanoli-Filippaki, A., 2008. Cost efficiency of the banking industry in the South Eastern European region. J. Int. Financ. Mark. Institutions Money 18, 483 497. doi:https://doi.org/10.1016/j.intfin.2007.07.003

Swamy, P.A.V.B., 1970. Efficient inference in a random coefficient regression model. Econom. J. Econom. Soc. 38, 311-323.

Swets, J.A., 2014. Signal detection theory and ROC analysis in psychology and diagnostics: Collected papers. Psychology Press.

Uddin, H.M., Humayun Kabir, S., Mollah, S., 2017. Corporate earnings uncertainty in Islamic banking system: An analysis and evidence, in: KFUPM Islamic Banking and Finance Research Conference 2017.

Usmani, T., 2004. An introduction to Islamic finance. Arham Shamsi.

Warde, I., 2000. Islamic finance in the global economy. Edinburgh University Press.

Weill, L., 2009. Convergence in banking efficiency across European countries. J. Int. Financ. Mark. Institutions Money 19, 818-833. doi:10.1016/j.intfin.2009.05.002

West, D., 2000. Neural network credit scoring models. Comput. Oper. Res. 27, 1131-1152.

Young, A.T., Higgins, M.J., Levy, D., 2008. Sigma convergence versus beta convergence: Evidence from U.S. county-level data. J. Money, Credit Bank. 40, 1083-1093. doi:10.1111/j.15384616.2008.00148.x

Yudistira, D., 2004. Efficiency in Islamic banking: An empirical analysis of eighteen banks. Islam. Econ. Stud. 12, 2-19.

Zaher, T.S., Kabir Hassan, M., 2001. A comparative literature survey of Islamic finance and banking. Financ. Mark. Institutions Instruments 10, 155-199.

Zaman, M.R., Movassaghi, H., 2002. Interest-free Islamic banking: Ideals and reality. Int. J. Financ. 14. Zhang, T., Matthews, K., 2012. Efficiency convergence properties of Indonesian banks 1992-2007. 
Appl. Financ. Econ. 22, 1465-1478. doi:10.1080/09603107.2012.663468 


\section{Appendix 1: The translog output distance function}

The translog output distance function is defined below for $N$ banks using inputs $x_{k}(k=1, \ldots, K)$ to produce outputs $y_{m}(m=1, \ldots, M)$ :

$$
\begin{gathered}
\ln D_{i t}(x, y)=\alpha_{0}+\sum_{m=1}^{M} \alpha_{m} \ln y_{m i t}+\frac{1}{2} \sum_{m=1}^{M} \sum_{n=1}^{M} \alpha_{m m} \ln y_{m i t} \ln y_{n i t}+\sum_{k=1}^{K} \beta_{k} \ln x_{k i t}+ \\
\frac{1}{2} \sum_{k=1}^{K} \sum_{l=1}^{K} \beta_{k l} \ln x_{k i t} \ln x_{l i t}+\sum_{k=1}^{K} \sum_{m=1}^{M} \delta_{k m} \ln x_{k i t} \ln y_{m i t} \quad i=1,2, \ldots, N \text { (A1.1) }
\end{gathered}
$$

where subscript it refers to bank $i$ in time period $t$. Distance function restrictions require the following conditions to hold:

a) Homogeneity of degree +1 in outputs

$$
\begin{aligned}
& \sum_{m=1}^{M} \alpha_{m}=1 \quad \text { and } \\
& \sum_{n=1}^{M} \alpha_{m n}=0 \quad m=1,2, \ldots, M \quad \text { and } \\
& \sum_{m=1}^{M} \delta_{k m}=0 \quad k=1,2, \ldots, K
\end{aligned}
$$

b) Symmetry

$$
\begin{aligned}
& \alpha_{m n}=\alpha_{n m} \quad m, n=1,2, \ldots, M \text { and } \\
& \beta_{k l}=\beta_{l k} \quad k, l=1,2, \ldots, K
\end{aligned}
$$

By the homogeneity restriction $D(x, \omega y)=\omega D(x, y)$ and so one output can be chosen arbitrarily, for example the $M$ th output, such that $\omega=1 / y_{M}$. Thus equation (A1.1) can be written as:

$$
\begin{gathered}
-\ln y_{M i t}= \\
\alpha_{0}+\sum_{m=1}^{M-1} \alpha_{m} \ln \left(\frac{y_{m i t}}{y_{M i t}}\right)+\frac{1}{2} \sum_{m=1}^{M-1} \sum_{n=1}^{M-1} \alpha_{m n} \ln \left(\frac{y_{m i t}}{y_{M i t}}\right) \ln \left(\frac{y_{\text {nit }}}{y_{M i t}}\right)+\sum_{k=1}^{K} \beta_{k} \ln x_{k i t}+ \\
\frac{1}{2} \sum_{k=1}^{K} \sum_{l=1}^{K} \beta_{k l} \ln x_{k i t} \ln x_{l i t}+\sum_{k=1}^{K} \sum_{m=1}^{M-1} \delta_{k m} \ln x_{k i t} \ln \left(\frac{y_{m i t}}{y_{M i t}}\right)+\varepsilon_{i t} \quad i=1,2, \ldots, N
\end{gathered}
$$

where $\varepsilon_{i t}=-\ln D_{i t}(x, y)$

The quantity which is of interest here is the distance (or efficiency) $\ln D_{i t}(x, y)$ which is measured by the error term in equation (A1.4). We assume this error term can be split into two components i.e. $\varepsilon_{i t}=v_{i t}-u_{i t}$ where $v_{i t}$ represents statistical noise, i.e., $v_{i t} \sim N\left(0, \sigma_{v}^{2}\right)$, and $u_{i t}$ represents the efficiency of bank $i$ in time period $t$ and is distributed as half-normal i.e. $u_{i t} \sim N^{+}\left(\mu, \sigma^{2}\right)$, following (Aigner et al. 1977). 


\section{Appendix 2: Convergence model estimation}

The following conditional $\beta$-convergence model is estimated

$$
\begin{gathered}
\ln \left(u_{i, t}\right)-\ln \left(u_{i, t-1}\right)= \\
\alpha+\beta \ln \left(u_{i, t-1}\right)+\gamma \operatorname{TYPE}_{i, t}+\delta \operatorname{TYPE}^{2} \ln \left(u_{i, t-1}\right)+\sum \vartheta_{c} \operatorname{COUNTRY}_{c, i, t}+\sum \omega_{t} \mathrm{YEAR}_{i, t}+\varepsilon_{i, t}
\end{gathered}
$$

TYPE is a binary variable with 1 denoting an Islamic bank, zero otherwise. Country dummies (COUNTRY) and year dummies (YEAR) are included to account for differences in financial regimes and technology across countries and time.

If $\gamma \neq 0$ then Islamic and conventional banks are converging on different steady state efficiency levels; if $\delta \neq 0$ then Islamic and conventional banks have different convergence rates.

The convergence model presented above presupposes that differences between banks will depend solely on the business model (i.e. Islamic or conventional). Yet there may be some Islamic banks whose behaviour is more typical of conventional banks than of Islamic banks, and vice versa. In order to allow for differences between individual banks as revealed by the data (rather than as imposed by the analyst) the following $\beta$-convergence model is estimated using the random parameter model (RPM).

$$
\ln \left(u_{i, t}\right)-\ln \left(u_{i, t-1}\right)=\alpha_{i}+\beta_{i} \ln \left(u_{i, t-1}\right)+\varepsilon_{i, t}
$$

The estimated parameters $\left(\alpha_{i}, \beta_{i}\right)$ therefore allow each bank a) to have a different steady state efficiency and b) to react differently to its past efficiency level. In order to see whether there are differences between Islamic and conventional banks we subsequently examine the $\alpha_{i}$ and $\beta_{i}$ estimates for possible differences between the bank types. While a random parameter stochastic frontier approach has been applied to estimating bank efficiencies in the context of Mexico (Barros and Williams, 2013), the random parameter approach has not been applied in the context of banking efficiency convergence. 


\section{Appendix 3: Classification trees}

While no asymptotic theory exists, the virtue of the algorithm underpinning the classification trees methodology lies in its ability to reveal multidimensional data splits (Durlauf and Johnson, 1995). Classification trees can be seen as a type of variable selection procedure. The main difference is that in a stepwise regression the sample remains unchanged and the control variables are selected; in a classification tree the control variables are selected and the sample is allowed to vary. The classification trees procedure may be viewed as a union of piecewise linear functions, where observations are grouped according to the control variables. The splits are chosen with respect to minimising misclassification costs (Breiman et al. 1984). The essence of the algorithm is described here; for a full exposition of the classification tree algorithm see among others Breiman et al., (1984), Durlauf and Johnson (1995).

Assume $Y$ to be the variable of interest and $X_{1}, \ldots, X_{j}$ the control variables. The aim is to find a model for predicting $Y$ from $X_{1}, \ldots, X_{j}$ through binary recursive splits. Starting from a club equivalent to the entire population of banking systems, say $=\left\{i_{1}, i_{2}, \ldots, i_{n}\right\}$ (this can be referred to as step 0) the algorithm searches for the best binary splits in the dataset.

Step 1. For the data under investigation select a binary split, which is of the form $x_{j}<s$ versus $x_{j} \geq s$. The choice of the binary split consists of two components, the selected control variable $(j)$ and the realisation of the control variable $(s)$. The binary split creates two nodes that are subsequently tested for impurity. Impurity of a node is measured by the Gini's Diversity Index (GDI). ${ }^{13}$ The GDI of a node is given as $1-\sum_{i} p^{2}(i)$ where the sum is over the clubs $i$ at the node and $p(i)$ is the observed fraction of clubs with club $i$ that populate the node. A pure node has only one club and a GDI equal to zero; otherwise positive values of GDI measure the degree of impurity in the node where more than one clubs are present.

Therefore, at each splitting level the following expression is minimised:

$$
\Delta(h)=\min _{j s}\left\{\min _{c_{2}}\left(1-\sum_{i}\left(\frac{c_{1}}{c_{1}+c_{2}} \mid x_{i} \in R_{1, j s}\right)\right)+\min _{c_{1}}\left(1-\sum_{i}\left(\frac{c_{2}}{c_{1}+c_{2}} \mid x_{i} \in R_{2, j s}\right)\right)\right\}
$$

where the parameter $h$ denotes the splitting level with $h=1$ denoting the first level that two nodes exist. The variables of interest to the algorithm $(j, s)$ split the realisations of the $Y$ variable $\left(c_{1}, c_{2}\right)$ into two nodes $R_{1}, R_{2} \cdot{ }^{14}$ The lower the value of the quantity $1-\frac{c_{1}}{c_{1}+c_{2}}$ the higher the purity level of the first node.

Step 2. If one of the resulting nodes has zero impurity score then this is classified as a pure node and the branch is terminated here. Conversely, if one of the resulting nodes has a positive impurity score, then a further split may be possible.

Step 3. For the impure nodes, continue from step 1.

The algorithm finishes when the resulting nodes are either pure or cannot be broken down any further due to observation requirements.

\footnotetext{
${ }^{13}$ For a full exposition of impurity metrics used in this context we direct you to (Berzal et al., 2003).

${ }^{14}$ For ease of exposition we assume that the predictor variables are categorical variables.
} 
Accuracy is defined as the percentage of banking systems that are correctly predicted by the model as being of high/low convergence rate; see also (Delen et al., 2013).

The area under the receiver operating characteristic (AUROC) curve is used to gauge the performance of a binary classifier system, such as classification trees. An AUROC curve that is convex to the diagonal indicates that the proposed model is better in distinguishing positive and negative ranks (or in our case high vs low convergence banking systems) than randomness would imply. Irimia-Dieguez et al., (2015) offer an application of the AUROC curve in classification trees, with Swets (2014) offering a more detailed analysis.

Expected misclassification cost (EMC) is given as:

$$
E M C=C_{12} \pi_{2} F P R+C_{21} \pi_{1} F N R
$$

where $C_{12}$ and $C_{21}$ are the relative costs of misclassification with $C_{12}$ representing the case where a low convergence banking system is classified as a high one and $C_{21}$ represents the case where a high convergence banking system is not classified as a high one; $\pi_{2}, \pi_{1}$ are prior probabilities of high and low convergence banking systems; FPR and FNR denote the FalsePositive-Rate and False-Negative-Rate respectively. In terms of values, $C_{12}$ and $C_{21}$ are assumed equal to 1 and 5 respectively, in line with Irimia-Dieguez et al., (2015) and West (2000); $\pi_{2}, \pi_{1}$ are equal to 0.5 by definition of the median-split we imposed, while FPR and FNR are estimated from the data. 
Appendix 4: Estimated $\sigma$-convergence models

Table A4: $\sigma$--convergence model estimated using various estimation methods

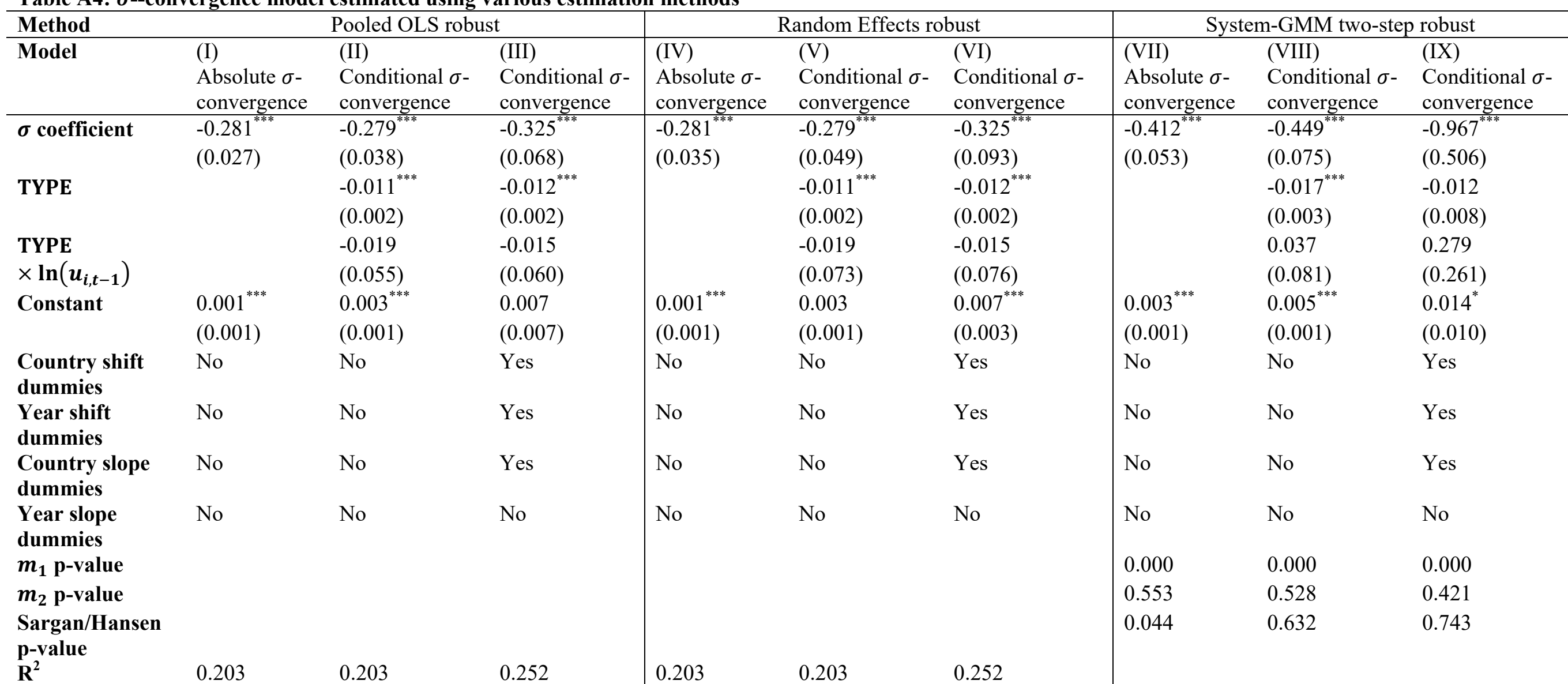

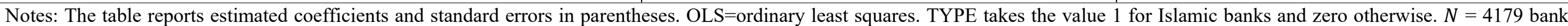

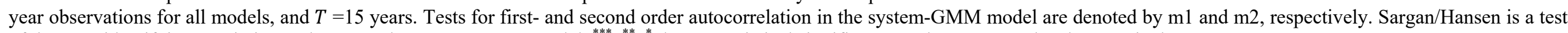
of the over-identifying restrictions relevant to the system-GMM model. ${ }^{* * *},{ }^{* *},{ }^{*}$ denote statistical significance at the $1,5,10 \%$ level respectively. 